Article

\title{
Sediment Management in Taiwan's Reservoirs and Barriers to Implementation
}

\author{
Hsiao-Wen Wang ${ }^{1}$, Mathias Kondolf ${ }^{2,3}{ }^{(\mathbb{D})}$, Desiree Tullos ${ }^{4}$ and Wei-Cheng Kuo ${ }^{1, *}$ \\ 1 Department of Hydraulic and Ocean Engineering, National Cheng Kung University, Tainan 701, Taiwan; \\ whw82@mail.ncku.edu.tw \\ 2 Collegium de Lyon-Institut des Etudes Avancées de l’Université de Lyon, 69007 Lyon, France; \\ kondolf@berkeley.edu \\ 3 Department of Landscape Architecture and Environmental Planning, University of California, \\ Berkeley, CA 94720-2000, USA \\ 4 Department of Biological and Ecological Engineering, Oregon State University, Corvallis, OR 97331, USA; \\ Desiree.Tullos@oregonstate.edu \\ * Correspondence: n88981070@gmail.com; Tel.: +886-6-275-7575
}

Received: 21 June 2018; Accepted: 1 August 2018; Published: 4 August 2018

\begin{abstract}
Reservoirs play a critically important role in supplying water for human uses. However, sedimentation limits storage capabilities and increases risk for aging infrastructure. The objectives of this paper are to synthesize both general sediment management strategies and past sediment management efforts in Taiwan in order to identify the barriers to more effective sediment management in reservoirs globally. A review of the broader literature and six Taiwan case studies was conducted to examine the characteristics, limitations, costs, and effectiveness of different sediment management strategies. Results highlight how social barriers play an important role in limiting reservoir sustainability, particularly the crisis-response approach to addressing sedimentation and the low priority for sediment management relative to competing objectives, such as tourism. Technical barriers are driven primarily by the engineering and costs of retrofitting existing dams and site conditions that may inhibit particular practices at any given site. Results also highlight tradeoffs in the effectiveness, costs, and time efficiency of various sediment management strategies in restoring storage capacity. The high sediment loads and rapid filling of reservoirs in Taiwan provide early insight into the management issues that are emerging worldwide, and these results emphasize the need for proactive engineering and management of sediment in reservoirs globally.
\end{abstract}

Keywords: sediment management; sedimentation; sustainability; reservoir life; Taiwan

\section{Introduction}

Accumulation of sediment can reduce reservoir life and, long before storage capacity is significantly affected, can interfere with functions of the reservoir [1]. While many large reservoirs were designed with dead storage sufficient to accommodate 100 years of sediment accumulation [2] and some large reservoirs could store centuries worth of incoming sediment before filling up completely [3], such long sedimentation horizons are rarely the case in areas with high sediment yields. Interruption of sediment continuity through the river system can also damage ecological systems and human infrastructure downstream of the dam [4].

With many dams reaching the end of their original design life [5,6], accumulation of sediment is becoming an increasingly important issue in reservoir management. The feasibility studies conducted for most existing reservoirs did not address costs of dam decommissioning and sediment management at the end of the design life, but these costs are substantial, as has been demonstrated at over 1200 dam 
removals [7]. Furthermore, few high-quality sites for new reservoirs remain [8], and thus the existing storage capacity is more valuable to maintain. Consequently, the potential benefits of managing sediments to maintain reservoir storage capacity has been acknowledged by many authorities [8-12] but to date has been implemented at relatively few sites.

Sustainable reservoirs, from a sediment management perspective, have been defined as those (a) whose life and reservoir capacity is maintained indefinitely, (b) whose economic value is positive when taking a full life cycle approach that considers decommissioning and sediment management at the end of the project life, and (c) that provide intergenerational equity by not burdening future generations with the social, environmental, or economic costs of natural resource use of previous generations $[10,13]$. All three concepts, either directly or indirectly, support the need for managing sediment throughout the life of the reservoir.

Sustainable sediment management to maintain reservoir capacity can be accomplished by a suite of strategies, as described in detail by Morris and Fan [9], Harada et al. [14], Kawashima et al. [12], and Annandale [8]. The most promising and long-term solutions include sediment bypass tunnels, as demonstrated in Japan and Switzerland [15,16], and sediment flushing [17,18]. However, the efficiency and feasibility of strategies vary according to their compatibility with operations at individual reservoirs, particularly those with carryover storage, synchrony with natural sediment supply, water demand for each unit of sediment managed, effectiveness in maintaining reservoir capacity, and ability to meet necessary infrastructure and hydraulic conditions, among other factors (Table 1). For instance, a reservoir with low capacity, which can be emptied and refilled quickly, could use flushing to release sediment downstream instead of allowing floodwater to escape over its spillway, but it would require that a dam have low level outlets. Instead, sediment yield reduction by erosion control and sediment retention structures upstream does not require either low level outlets or drawdown and may be applied at reservoirs of all sizes. However, the effectiveness relative to sediment yield is only moderate at best. Furthermore, these strategies are rarely implemented before a reservoir evinces negative effects of sediment accumulation, at which point it may be too late to implement some strategies. The literature reporting experience implementing multiple sediment management strategies is limited, with the exceptions of Japan (e.g., [19]) and Switzerland (e.g., [20]). By synthesizing multiple experiences in sediment management in a region, it may be possible to extract lessons that can inform future sediment management challenges elsewhere.

With its extremely high sediment yields, Taiwan supplies the oceans with $384 \mathrm{M}$ tonnes of suspended sediment per year, about $1.9 \%$ of the world's total, from its $36,000 \mathrm{~km}^{2}$ (only $0.024 \%$ of the world's land area) [21]. The highly seasonal precipitation pattern in Taiwan means that water storage is critical to meeting water demands during the long dry season and in dry years. At present, 61 major reservoirs in Taiwan impound a total of 2.2 billion $\mathrm{m}^{3}$ for municipal, industrial, and agricultural water supply to Taiwan's 23 million residents. Taiwan's dependence on reservoir storage and its high sediment yields mean management of reservoir sediment is particularly important (Figure 1, Table 2), as clearly identified by Hwang [22]. However, despite decades of research and engineering, implementation of sediment management in Taiwan's reservoirs has been relatively slow and sometimes ineffective for a variety of social, technical, environmental and economic reasons. In this study, current and historical sediment management strategies were documented for six reservoirs to identify barriers to effective management and to assess the tradeoffs among sediment management strategies. 
Table 1. Characteristics and limitations of sediment management strategies. For strategies identified as "depends," the local decisions about the strategy determine if the strategy contributes to the characteristic (Annandale et al. [8]; Morris and Fan [9]; Kondolf et al. [18]).

\begin{tabular}{|c|c|c|c|c|c|c|c|c|c|c|c|}
\hline $\begin{array}{l}\text { Sediment } \\
\text { Management } \\
\text { Strategy }\end{array}$ & $\begin{array}{l}\text { Requires } \\
\text { Low Level } \\
\text { Outlets }\end{array}$ & $\begin{array}{c}\text { Requires } \\
\text { Drawdown }\end{array}$ & $\begin{array}{c}\text { Maintenance } \\
\text { of Reservoir } \\
\text { Capacity }^{1}\end{array}$ & $\begin{array}{l}\text { Appropriate } \\
\text { Reservoir } \\
\text { Size }\end{array}$ & $\begin{array}{l}\text { Ability to } \\
\text { Remove } \\
\text { Deposited } \\
\text { Sediments }\end{array}$ & $\begin{array}{l}\text { Addresses } \\
\text { Downstream } \\
\text { Sediment } \\
\text { Starvation }\end{array}$ & $\begin{array}{l}\text { Sediment Release } \\
\text { Consistent with Scale } \\
\text { and Timing of Natural } \\
\text { Sediment Events }\end{array}$ & $\begin{array}{c}\text { Provides } \\
\text { Supply of } \\
\text { Aggregates }\end{array}$ & $\begin{array}{c}\text { Potential to } \\
\text { Affect Water } \\
\text { Supply for } \\
\text { Beneficial Uses }\end{array}$ & $\begin{array}{l}\text { Grain Size } \\
\text { Affected }\end{array}$ & $\begin{array}{l}\text { Effectiveness } \\
\text { Relative to } \\
\text { Sediment } \\
\text { Yield }^{1}\end{array}$ \\
\hline Doing nothing ${ }^{2}$ & no & no & no & none & no & no & NA & no & none & none & none \\
\hline $\begin{array}{l}\text { Sediment yield } \\
\text { reduction }{ }^{3}\end{array}$ & no & no & medium & all & no & no & NA & no & none & none & medium \\
\hline Dredging 4 & no & no & low & all & yes & depends & NA & yes & yes & coarse & low \\
\hline $\begin{array}{l}\text { Hydrosuction and } \\
\text { wet/hydraulic } \\
\text { dredging }{ }^{5}\end{array}$ & no & no & low & all & yes & depends & no & depends & high & fine & low \\
\hline $\begin{array}{l}\text { Drawdown flushing } \\
\text { during non-flood } \\
\text { season }{ }^{6}\end{array}$ & yes & yes & high & small & yes & yes & no & no & yes & all & high \\
\hline $\begin{array}{l}\text { Routing-venting } \\
\text { turbidity currents }\end{array}$ & yes & no & high & large & no & yes & yes & no & low & fine & medium \\
\hline $\begin{array}{l}\text { Routing-drawdown } \\
\text { pass-through during } \\
\text { floods } 8\end{array}$ & yes & yes & high & small & no & yes & yes & no & low & fine & medium \\
\hline $\begin{array}{l}\text { Routing-off-stream } \\
\text { reservoir }{ }^{9}\end{array}$ & no & no & high & all & no & yes & yes & no & none & all & high \\
\hline $\begin{array}{l}\text { Routing-sediment } \\
\text { bypass } 10\end{array}$ & no & no & high & all & no & yes & yes & no & low & all & high \\
\hline
\end{tabular}

Designation is subjective based on review of literature. ${ }^{2}$ No sediment management. ${ }^{3}$ Via erosion control and sediment retention structures. ${ }^{4}$ Coarse sediment deposited in the reservoir pipeline outlet. ${ }^{6}$ Reservoir is emptied during non-flood season to scour and transport stored sediment. ("flushing"). ${ }^{7}$ Operators open low-level outlets when a dense turbidity current (high suspended sediment concentration) is detected in the upstream reaches of the reservoir ${ }^{8}$ Reservoir is emptied during the flood season to pass sediment to avoid net accumulation. ("sluicing"). ${ }^{9}$ Flows are diverted into a reservoir constructed off-stream during periods of low sediment concentrations. ${ }^{10}$ Sediment-rich flood flows as diverted from upstream end of reservoir via a high-capacity channel or tunnel. 
Table 2. Reservoir capacity sedimentation in Taiwan (data courtesy of Taiwan Water Resources Agency (WRA), Taipower Company, Taiwan Sugar Corporation, and Taiwan Water Corporation).

\begin{tabular}{|c|c|c|c|c|c|c|c|c|}
\hline $\begin{array}{c}\text { Reservoir } \\
\text { (Years of Record) }\end{array}$ & $\begin{array}{l}\text { Drainage Area } \\
\left(\mathrm{km}^{2}\right)\end{array}$ & $\begin{array}{l}\text { Initial Storage } \\
\text { Capacity }\left(10^{3} \mathrm{~m}^{3}\right)\end{array}$ & $\begin{array}{c}\text { Period of } \\
\text { Record (years) }\end{array}$ & $\begin{array}{l}\text { Storage } \\
\text { Depletion } \\
\left(10^{3} \mathrm{~m}^{3}\right)\end{array}$ & $\begin{array}{c}\text { Average Annual } \\
\text { Sediment } \\
\text { Accumulation }\left(10^{3} \mathrm{~m}^{3}\right)\end{array}$ & $\begin{array}{l}\text { Denudation } \\
\text { Rate }^{1}(\mathrm{~mm})\end{array}$ & $\begin{array}{c}\text { Average Annual } \\
\text { Storage Depletion of } \\
\text { Initial Capacity (\%) }\end{array}$ & $\begin{array}{c}\text { Probable Remaining } \\
\text { Reservoir Life } \\
\text { (years) }\end{array}$ \\
\hline & (A) & (B) & (C) & (D) & (E) & $(F)=E / A$ & $(G)=E / B$ & $(H)=(B-D) / E$ \\
\hline Feitsui (1984-2013) & 303 & 406,000 & 29.5 & 24,449 & 829 & 2.7 & 0.2 & 460 \\
\hline Ronghua (1983-2014) & 561 & 12,400 & 31 & 12,310 & 397 & 0.7 & 3.2 & 0 \\
\hline Shihmen (1963-2015) & 763.4 & 309,120 & 52 & 100,861 & 1940 & 2.5 & 0.6 & 107 \\
\hline Tapu (1960-2010) & 100 & 9260 & 50 & 3850 & 77 & 0.8 & 0.8 & 70 \\
\hline Minte (1970-2009) & 61.1 & 17,700 & 39 & 5340 & 137 & 2.2 & 0.8 & 90 \\
\hline Techi (1973-2013) & 592 & 262,210 & 40 & 67,520 & 1688 & 2.9 & 0.6 & 115 \\
\hline Wujie (1934-1993) & 501 & 14,000 & 59 & 13,930 & 236 & 0.5 & 1.7 & 0 \\
\hline Wusheh (1959-2014) & 219 & 148,600 & 55 & 103,540 & 1883 & 8.6 & 1.3 & 24 \\
\hline Zengwen (1973-2015) & 481 & 748,400 & 42.5 & 280,391 & 6593 & 13.7 & 0.9 & 71 \\
\hline Paiho (1965-2009) & 26.6 & 25,090 & 44 & 18,120 & 412 & 15.5 & 1.6 & 17 \\
\hline Jensanpi (1938-2012) & 10.3 & 8110 & 74 & 6604 & 89 & 8.7 & 1.1 & 17 \\
\hline Wusantou (1930-2010) & 58.2 & 154,150 & 80 & 75,870 & 948 & 16.3 & 0.6 & 83 \\
\hline \multirow{2}{*}{$\begin{array}{l}\text { Agongdian (1953-1998) } \\
\text { Agongdian (2005-2015) }\end{array}$} & \multirow{2}{*}{31.9} & 36,700 & 45 & 19,525 & 416 & 13.0 & 1.1 & 41 \\
\hline & & 18,370 & 10.2 & 2081 & 205 & 6.4 & 1.1 & 80 \\
\hline Nanhua (1993-2014) & 108.3 & 154,410 & 21 & 57,520 & 2739 & 25.3 & 1.8 & 35 \\
\hline
\end{tabular}

${ }^{1}$ Average annual depth eroded from drainage area. 


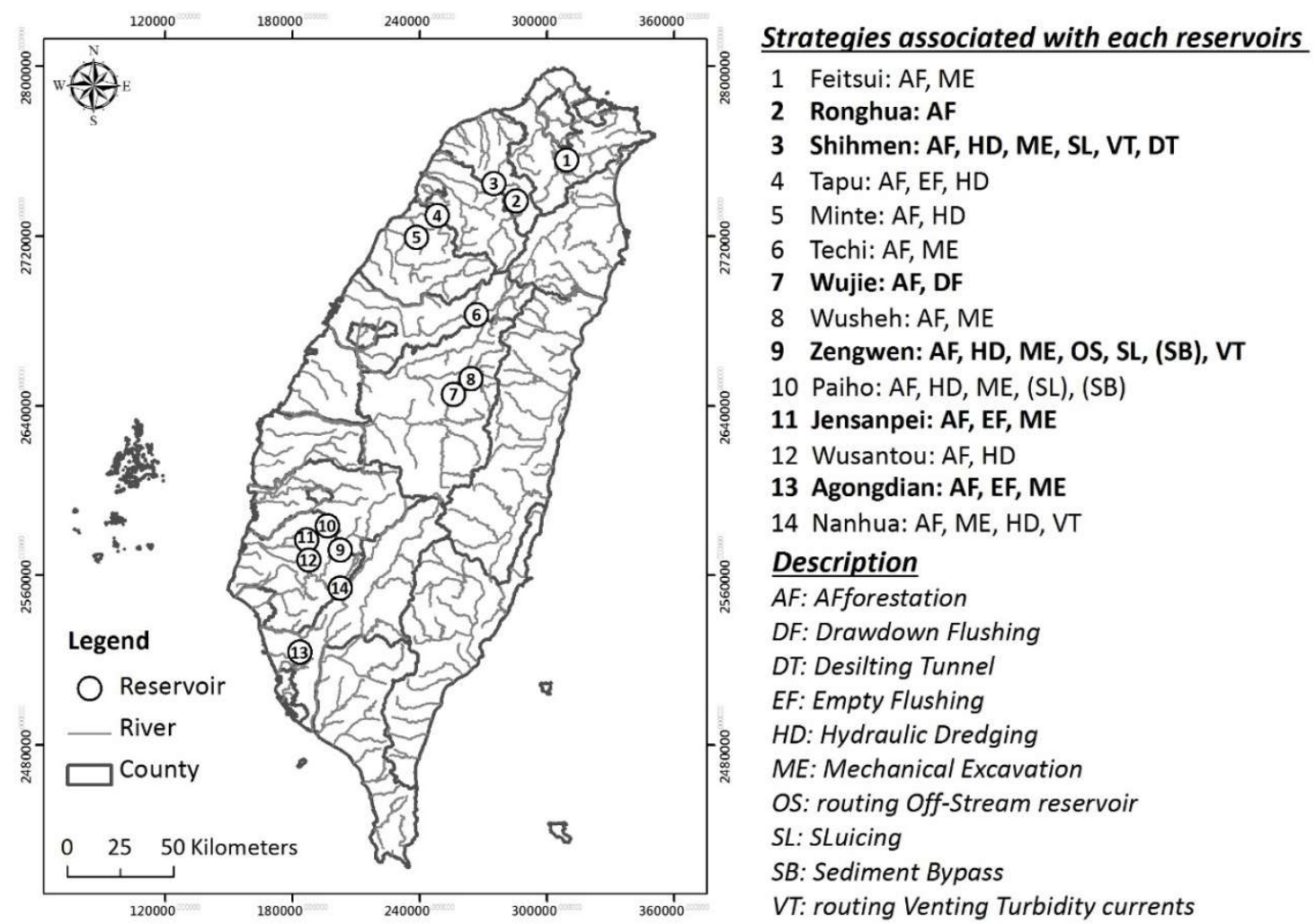

Figure 1. Locations of some of the reservoirs in Taiwan and strategies associated with each reservoir. Those highlighted in bold are the case study sites (data courtesy of WRA, Taipower Company, Taiwan Sugar Corporation, and Taiwan Water Corporation).

\section{Sediment Yield to Reservoirs of Taiwan}

Tectonically shattered subduction trench lithologies, rapid uplift, and intense monsoon and typhoonal rains combine to produce rapid erosion rates that make Taiwan's reservoir sedimentation rates to be among the highest in the world [21]. By virtue of its tectonic setting at the collision of the Luzon arc and the Asian continental margin, the Taiwan orogen is one of Earth's most geologically active. The steep slopes, regular earthquakes, and intense rainfall lead to regular landslides and debris flows across the island [23,24].

However, the substantial variability in the precipitation patterns, valley slopes, and rock resistance across the island lead to substantial differences in the sediment yields. These differences combined with variability in dam design and operation result in differences in the optimal strategies for sediment management among individual dams that may reflect variations at the global scale. For example, Taiwan's climate spans four of Köppen's climate classifications, including Monsoon and Trade-Wind Coastal Climate (Am) in the south, Mild, Humid Climate (Cfa) in the north, Wet-Dry Tropical Climate (Cwa) in the west, and Temperate Rainy Climate with Dry Winter (Cw) in mountain areas. The island's average annual precipitation varies from $2500 \mathrm{~mm}$ to over $3000 \mathrm{~mm}$. The monsoonal precipitation is highly orographic, with average precipitation about $2200 \mathrm{~mm}$ in plain areas and $3800 \mathrm{~mm}$ in mountain areas annually [25]. Precipitation is highly seasonal across the island, but also varies spatially, with a wet-dry season rainfall ratio of 1.5 in northern Taiwan and a ratio of 9 in southern Taiwan [22]. Furthermore, compressive rock strength varies over three orders of magnitude, generally increasing from south to north and from west to east [21]. 
This geographical variability is expressed in the island's variable denudation rates (rates of land lowering from erosion averaged over large areas), which range from $60 \mathrm{~mm} / \mathrm{yr}$ in Southern Taiwan to 1-4 mm/year in the North and West of Taiwan [21]. Individual reservoirs have lost from $77 \times 10^{3} \mathrm{~m}^{3}$ to $6600 \times 10^{3} \mathrm{~m}^{3}$ in capacity, with generally lower storage depletion rates for reservoirs draining northern basins (Table 2). Thus, as in other regions of the globe, the appropriateness of given sediment management strategies is likely to vary across Taiwan with the geology and hydrology.

\section{Methods}

We selected six case studies of reservoirs that had experienced sedimentation problems to the point that required extensive interventions to maintain or restore dam function and/or storage capacity. These case studies were selected in part due to the sufficiency of data and documentation on sediment management (Table 3, Figure 2). We calculated the empirical indexes, i.e., the capacity-inflow ratio and the capacity-sediment inflow ratio, for each case at its initial and present $([9,11])$. Data on sedimentation rates, loss of storage capacity, and sediment management strategies employed were compiled and the checklist of Annandale et al. [8] was applied to document the degree of sediment planning and management at the case studies. Three of the case studies involved multiple sediment management strategies over time and were especially well documented and thus were reported in greater detail (Table 4).

The case studies spanned a range of river and dam sizes, management objectives, and diverse geographical contexts (Table 3). Two of them are large reservoirs with initial reservoir capacity exceeding $10 \mathrm{Mm}^{3}$, while the other four impound between $5 \mathrm{Mm}^{3}$ and $10 \mathrm{Mm}^{3}$. Half of the dams exceed $60 \mathrm{~m}$ in height, while the other half are between $15 \mathrm{~m}$ and $60 \mathrm{~m}$. Four of them are hydrologically large reservoirs with the initial capacity-inflow ratio exceeding 0.2 and the capacity-sediment inflow ratio larger than 30. Three of them are located in northern Taiwan, one in central, and two others in southern Taiwan. In terms of ownership and operating authority, four of them are owned and operated by Taiwan Water Resources Agency (WRA), one by Taipower Company, and one by Taiwan Sugar Corporation. Taipower Company is a state-owned electric power industry providing electricity to Taiwan and off-shore islands, while Taiwan Sugar Corporation is a state-run enterprise leading sugar production and sales of Taiwan. 


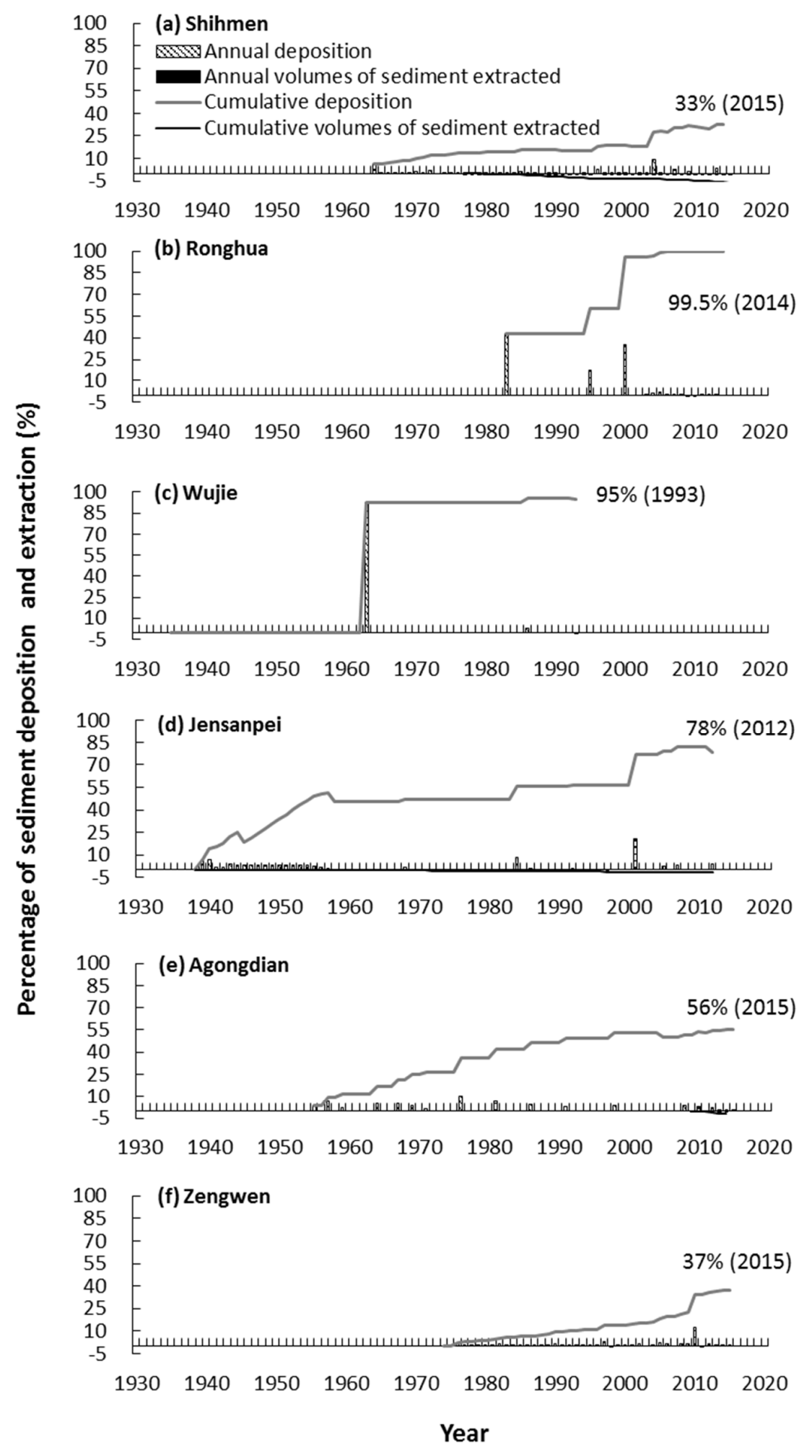

Figure 2. Reservoir sedimentation and removal over time. The percent capacity lost is reported along with the year of last reservoir survey at the end of each plot (data courtesy of WRA, Taipower Company, and Taiwan Sugar Corporation); (a) Shihmen Reservoir; (b) Ronghua Reservoir; (c) Wujie Reservoir; (d) Jensanpei Reservoir; (f) Zengwen Reservoir. 
Table 3. Overview of case studies (data courtesy of WRA, Taipower Company, and Taiwan Sugar Corporation). Reservoir Objectives are defined as Municipal and Industrial (M\&I), Irrigation (IR), Industrial (ID), Hydropower generation (HP), Recreation (R), Sediment Control (SC), and Flood Control (FC).

\begin{tabular}{|c|c|c|c|c|c|c|c|c|c|c|c|c|}
\hline $\begin{array}{c}\text { Reservoir } \\
\text { (River) }\end{array}$ & $\begin{array}{c}\text { Year } \\
\text { Completed }\end{array}$ & $\begin{array}{l}\text { Reservoir } \\
\text { Objective }\end{array}$ & Dam Type & $\begin{array}{l}\text { Dam } \\
\text { Height } \\
\text { (m) }\end{array}$ & $\begin{array}{l}\text { Initial } \\
\text { Storage } \\
\text { Capacity } \\
\left(10^{3} \mathrm{~m}^{3}\right)\end{array}$ & $\begin{array}{l}\text { Live } \\
\text { Storage } \\
\left(10^{3} \mathrm{~m}^{3}\right)\end{array}$ & $\begin{array}{c}\text { Mean Annual } \\
\text { Runoff } \\
\left(10^{3} \mathrm{~m}^{3}\right)\end{array}$ & $\begin{array}{c}\text { Mean Annual } \\
\text { Sediment Load } \\
\left(10^{3} \mathrm{~m}^{3}\right)\end{array}$ & $\begin{array}{l}\text { Initial } \\
\text { Capacity- } \\
\text { Inflow } \\
\text { Ratio }\end{array}$ & $\begin{array}{c}\text { Initial } \\
\text { Capacity- } \\
\text { Sediment } \\
\text { Ratio }\end{array}$ & $\begin{array}{c}\text { Current } \\
\text { Capacity- } \\
\text { Inflow } \\
\text { Ratio }\end{array}$ & $\begin{array}{c}\text { Current } \\
\text { Capacity- } \\
\text { Sediment } \\
\text { Ratio }\end{array}$ \\
\hline $\begin{array}{l}\text { Shihmen } \\
\text { (Dahan) }\end{array}$ & 1964 & M\&I, IR, HP, FC, R & Embankment Dam & 133.1 & 309,120 & 208,259 & $\begin{array}{c}1,468,000 \\
(1964-2015)\end{array}$ & 3530 & 0.21 & 88 & 0.14 & 59 \\
\hline $\begin{array}{l}\text { Ronghua } \\
\text { (Dahan) }\end{array}$ & 1984 & $\mathrm{HP}, \mathrm{SC}$ & Concrete Arch Dam & 82 & 12,400 & 90 & $\begin{array}{c}1086,526 \\
(2001-2015)\end{array}$ & 2800.9 & 0.01 & 6 & 0.00 & 0.04 \\
\hline $\begin{array}{c}\text { Wujie } \\
\text { (Jhuoshuei) }\end{array}$ & 1934 & $\mathrm{HP}$ & Concrete Gravity Dam & 57.6 & 14,000 & 70 & $\begin{array}{c}1,278,955 \\
(2001-2015)\end{array}$ & 1728 & 0.01 & 8 & 0.00 & 0.04 \\
\hline $\begin{array}{l}\text { Jensanpi } \\
\text { (Chiesui) }\end{array}$ & 1938 & $\begin{array}{l}\text { IR, ID; after 2001, } \\
\text { only R }\end{array}$ & $\begin{array}{l}\text { Concrete Core } \\
\text { Embankment Dam }\end{array}$ & 30 & 8110 & 1506 & $\begin{array}{c}7163 \\
(2001-2015)\end{array}$ & 247 & 1.13 & 33 & 0.21 & 6 \\
\hline $\begin{array}{l}\text { Agongdian } \\
\text { (Agongdian) }\end{array}$ & $\begin{array}{l}1953 \\
2005\end{array}$ & FC, IR, M\&I (2011 ) & Earth Fill & 31 & $\begin{array}{l}36,700 \\
18,370\end{array}$ & $\begin{array}{l}17,175 \\
16,290\end{array}$ & $\begin{array}{c}54,871 \\
(2001-2015)\end{array}$ & 386.7 & $\begin{array}{l}0.67 \\
0.33\end{array}$ & $\begin{array}{l}95 \\
48\end{array}$ & $\begin{array}{l}0.31 \\
0.30\end{array}$ & $\begin{array}{l}44 \\
42\end{array}$ \\
\hline $\begin{array}{l}\text { Zengwen } \\
\text { (Zengwen) }\end{array}$ & 1973 & M\&I, IR, HP, R, FC & Embankment Dam & 133 & 748,400 & 468,009 & $\begin{array}{c}1,153,751 \\
(1975-2015)\end{array}$ & 5630 & 0.65 & 133 & 0.41 & 83 \\
\hline
\end{tabular}


Table 4. Summary of sediment management strategies at three case studies. Data are from WRA [26-34].

\begin{tabular}{|c|c|c|c|}
\hline Strategies & Shihmen & Agongdian & Zengwen \\
\hline Sediment yield reduction & $35.7 \mathrm{Mm}^{3}, 124$ check dams (1958-2004), \$66.6 M USD & N/A & $\begin{array}{l}\text { Afforestation, } 33 \text { check dams (1970-1993), land use } \\
\text { controls, \$40 M USD }\end{array}$ \\
\hline $\begin{array}{l}\text { Mechanical excavation } \\
\text { dry dredging }\end{array}$ & $\begin{array}{l}\text { (a) } 2.6 \mathrm{Mm}^{3} \text { (2006-2015) from downstream-most check dam (Yixing Dam), } \\
2 \mathrm{USD} / \mathrm{m}^{3} \\
\text { (b) } 1.7 \mathrm{Mm}^{3} \text { (2002-2015) from upstream most of the impoundment (Luofu Bridge), } \\
0.7 \mathrm{USD} / \mathrm{m}^{3} \\
\$ 6.6 \mathrm{M} \mathrm{USD}\end{array}$ & $\begin{array}{l}11.6 \mathrm{Mm}^{3} \text { (1997-2006, } \\
\text { during renovation project), } \\
0.07 \mathrm{Mm}^{3} \text { (2013-2014) }\end{array}$ & $\begin{array}{l}4.6 \mathrm{Mm}^{3}(2009-2015), 13 \mathrm{USD} / \mathrm{m}^{3} \\
\text { (including excavation from sediment traps above } \\
\text { reservoir), } \$ 60 \mathrm{M} \text { USD }\end{array}$ \\
\hline $\begin{array}{l}\text { Wet/hydraulic dredging } \\
\text { USD/year }\end{array}$ & $\begin{array}{l}\text { Combination with dredging; calculate annual and separate out into hydraulic } \\
\text { dredging and dry dredging } \\
\text { (a) } 8.1 \mathrm{Mm}^{3}(1985-2015) \text { from lower reaches of the impoundment, } 20 \mathrm{USD} / \mathrm{Mm}^{3} \text {, } \\
\$ 160 \mathrm{M} \mathrm{USD} \\
\text { (b) } 6.7 \mathrm{Mm}^{3} \text { (1977-2005) from middle reaches of the impoundment, cost unknown }\end{array}$ & No & $\begin{array}{l}\text { Hydraulic dredging and Clamshell dredging } \\
2 \mathrm{Mm}^{3}(2012 \sim 2015), 8 \mathrm{USD} / \mathrm{m}^{3}, \$ 16.7 \mathrm{M} \text { USD }\end{array}$ \\
\hline Sluicing & $\begin{array}{l}\text { (a) } 0.9 \mathrm{Mm}^{3} \text { (2012-2015), water diversion tunnel (PRO) retrofit to pass sediment in } \\
2012, \$ 1.8 \mathrm{M} \text { USD } \\
\text { (b) } 0.2 \mathrm{Mm}^{3} \text { (2008-2015), diversion way renovation project, } \$ 1.5 \mathrm{M} \text { USD } \\
\text { (c) } 1.8 \mathrm{Mm}^{3} \text { (2008-2015), tunnel spillway renovation project, \$30 M USD } \\
\text { (d) } 8.5 \mathrm{Mm}^{3}(2005-2015) \text {, power plant penstock } \\
\text { (e) } 1.9 \mathrm{Mm}^{3} \text { (2008-2015), spillway } \\
\text { (f) Estimated desilting amount: } 0.64 \mathrm{Mm}^{3} / \mathrm{yr} \text {, Amuping desilting tunnel would be } \\
\text { completed in 2021, } \$ 133.3 \mathrm{M} \text { USD }\end{array}$ & No & $\begin{array}{l}\text { 1.8 } \mathrm{Mm}^{3} \text { (2010-2015), water diversion tunnel retrofit } \\
\text { (\$18 M USD) to pass sediment in } 2008\end{array}$ \\
\hline $\begin{array}{l}\text { Routing-drawdown } \\
\text { pass-through during floods }\end{array}$ & No & Yes & No \\
\hline Sediment bypass & No, due to the tunnel cost & No & $\begin{array}{l}\text { No, under study but unlikely due to length of } \\
\text { reservoir }(>11 \mathrm{~km}) \text { and tunnel cost }\end{array}$ \\
\hline $\begin{array}{l}\text { Routing-venting turbidity } \\
\text { currents, one time } \\
\text { construction cost in USD }\end{array}$ & $\begin{array}{c}1.2 \mathrm{Mm}^{3} \text { (2013-2015), power plant retrofit to pass sediment in 2012, \$29 M USD } \\
\text { Estimated desilting amount: } 0.71 \mathrm{Mm}^{3} / \mathrm{yr} \text {, Dawanping desilting tunnel would be } \\
\text { completed in future, \$160 M USD }\end{array}$ & No & $\begin{array}{l}\text { Estimated desilting amount: } 1 \mathrm{Mm}^{3} / \mathrm{yr} \\
\text { \$133.3 M USD, sluicing tunnel would be completed in } \\
\text { December } 2017\end{array}$ \\
\hline Routing-off-stream reservoir & No & No & Yes, Wushantou Reservoir \\
\hline
\end{tabular}




\section{Case Study Summaries}

\subsection{Case Study 1: Shihmen Reservoir}

Shihmen Reservoir, constructed in 1963, supplies municipal water to 3.4 million people in the Taipei area, industrial and municipal water to Taoyuan County, a globally important high-technology industry area, and irrigation water for over 36,000 hectares [35]. Secondary objectives at Shihmen include power generation, recreation, and flood management. Within a year of its completion, the reservoir lost $6 \%$ of its capacity with the deposition of approximately $19 \mathrm{Mm}^{3}$ of sediment during a single typhoon. Despite many actions to manage sediment, Shihmen Reservoir had lost $33 \%$ of its capacity by 2015 (Figure 2a).

Strategies employed at Shihmen Reservoir (Figure 3, Table 4) to maintain the reservoir capacity have included construction of upstream sediment retention structures, modifying outlets at the dam, and mechanical dredging and hydraulic dredging (Figure $4 \mathrm{c}, \mathrm{d}$ ) to restore capacity by removing sediment already deposited in the reservoir. In an attempt to reduce sediment loads to the reservoir, authorities constructed over 120 sediment-control ("sabo") dams upstream, with capacities ranging from $54 \mathrm{~m}^{3}$ to 12.4 $\mathrm{Mm}^{3}$ (total capacity of $35.7 \mathrm{Mm}^{3}$ ), throughout the lower half of the catchment. The goals of sabo dams were both to retain sediment and to fix the bed elevation to prevent further incision and hillslope failure. The three largest dams, Ronghua, Barlin, and Yixing, with capacities of 12.4, 10.5, and 9.2 $\mathrm{Mm}^{3}$, respectively, were located on the mainstem Dahan River. Many of these sabo dams have filled with sediment and some have failed [36]. The failure in September 2007 of the second largest of these dams (Barlin Dam, Figure 4a) resulted in the sudden release of over $7.5 \mathrm{Mm}^{3}$ of stored sediment [36,37], and drew attention to the potential risks posed by these structures as they fill with sediment and deteriorate.

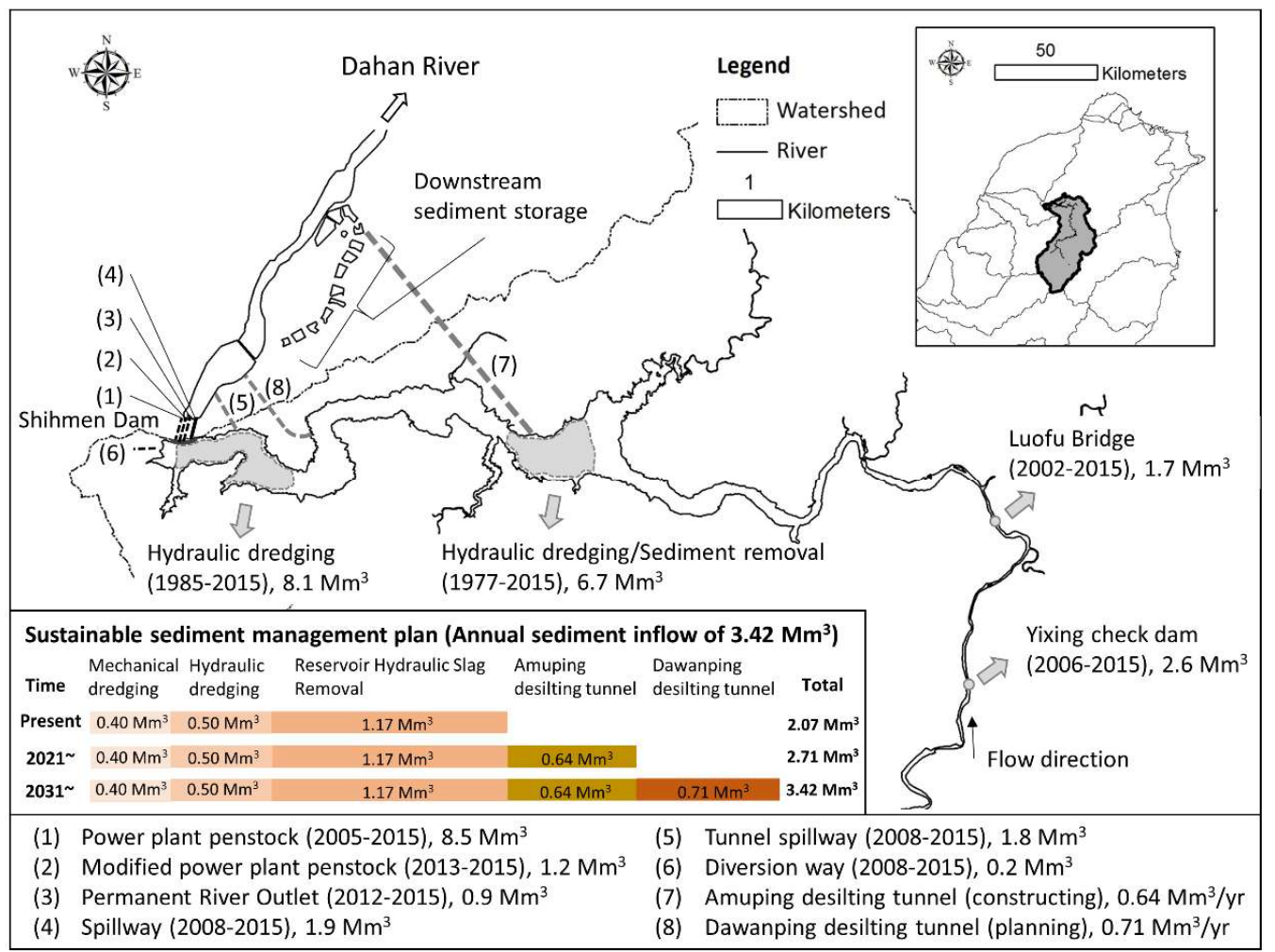

Figure 3. A diagrammatic map showing management strategies of Shihmen Reservoir. For each strategy, the years conducted are provided in parentheses, followed by the cumulative volume of sediment removed during implementation of that strategy, in $\mathrm{Mm}^{3}$. Data are from WRA [26-29]. 

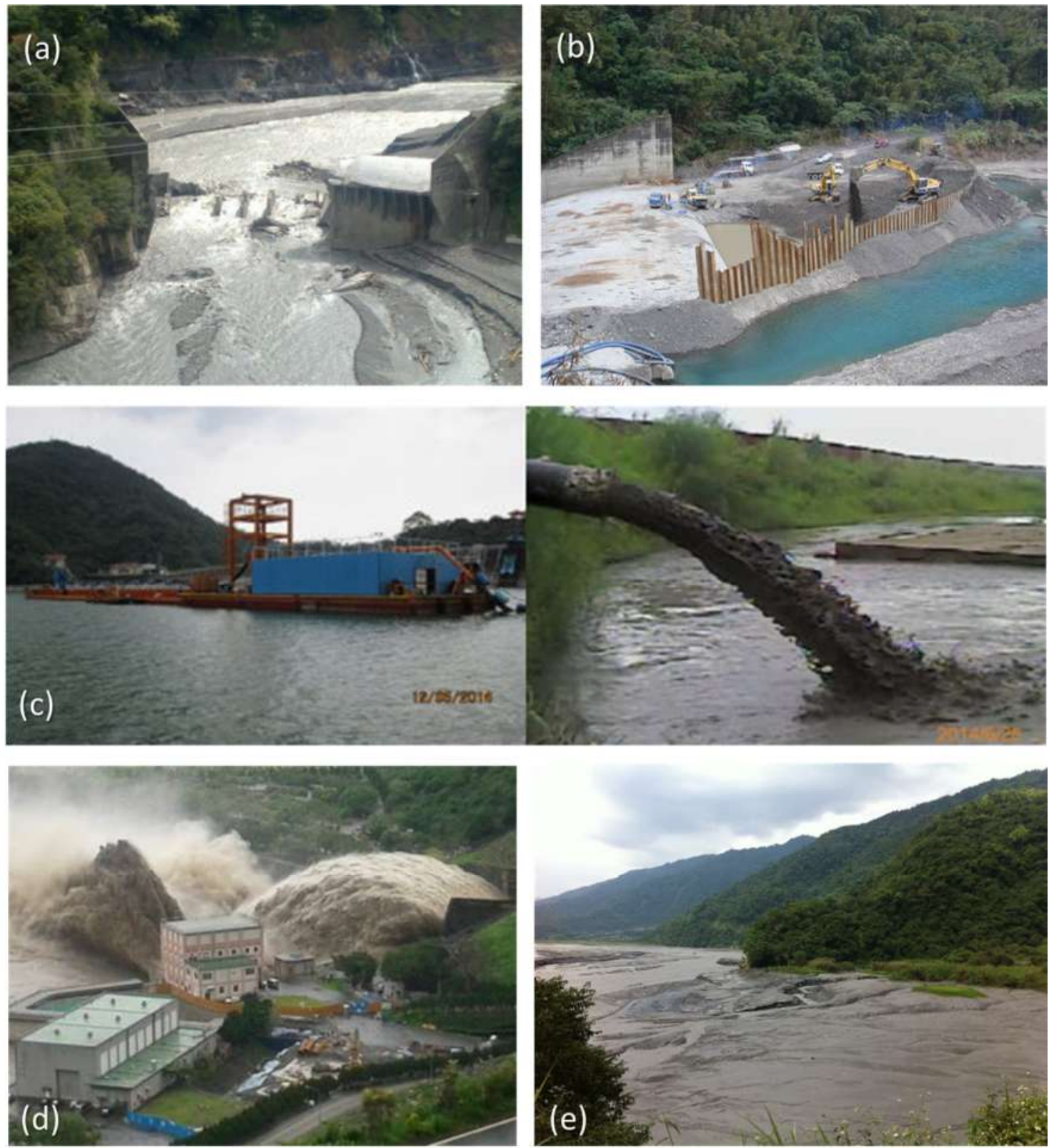

Figure 4. Images of sediment management strategies in Taiwan: (a) Barlin Dam, a failed sabo dam; (b) mechanical dredging from the lower most sabo dam, Yixing; (c) hydraulic dredging at Shihmen reservoir (WRA); (d) sluicing at Shihmen Reservoir during Typhoon Soulik in 2013 (WRA); (e) Drawdown flushing at Wujie Reservoir.

Between 1977 and 2015, the WRA has attempted to restore some of Shihmen's capacity via

1. Mechanically dredging $2.6 \mathrm{Mm}^{3}$ of sediment from the bed of the Dahan River from the lower most sabo dam, Yixing (2006-2015) (Figure 4b);

2. Mechanically dredging $1.7 \mathrm{Mm}^{3}$ upstream of the Shihmen Reservoir delta (2002-2015);

3. Mechanically and hydraulically dredging $6.7 \mathrm{Mm}^{3}$ from mid Shihmen Reservoir where sediments are half coarse- and half fine-grained (1977-2015); and

4. Hydraulically dredging $8.1 \mathrm{Mm}^{3}$ from lower Shihmen Reservoir where sediments are fine-grained (1985-2015) (Figure 4c) [26]. 
However, despite the high cumulative cost of this dredging ( \$160 M USD, 4.8 billion NTD), only $8 \%$ of the lost water storage capacity was restored, and capacity has not been maintained on a year-to-year basis (Figure 2a) due to high, sustained sediment inflows.

In August 2004, typhoon Aere produced flood flows with turbidity values on the order of 80,000 to $120,000 \mathrm{NTU}$, too high to be treated by water purification plants, causing municipal water supply to shut down for about 18 days and an industry loss of more than \$143 M USD [38]. The typhoons that year also produced debris that clogged intakes for the hydroelectric plant, and sediment yields that resulted in approximately $27.9 \mathrm{Mm}^{3}$ of deposition in Shihmen reservoir [26]. WRA spent about $\$ 1.6 \mathrm{M}$ USD on cleaning and repairing over two years. The impact to water supply made WRA more aware of the threat from reservoir sedimentation, motivating increased sediment monitoring and implementation of new sediment management strategies. As a result, WRA (1) constructed a surface intake shaft system with a capacity of $1.4 \times 10^{6} \mathrm{~m}^{3} /$ day to supply water (cost \$40 M USD), (2) renovated the low-level Permanent River Outlet (PRO), which releases downstream water supply during power plant failure, by replacing the original Howell-Bunger valve with a jet flow gate to allow sluicing during high flow events (cost \$1.8 M USD), and (3) renovated the power plant penstocks, replacing one penstock with a sluicing pipe and modifying the other penstock for electricity generation (cost \$29 M USD). Monitoring initiated in 2008 documented a total of $3.9 \mathrm{Mm}^{3}$ of sediment sluiced for years from 2008 to 2015 cumulatively by the spillway, tunnel spillway, and Shihmen irrigation channel [26-28]. Besides, $2.1 \mathrm{Mm}^{3}$ of sediment was sluiced between 2012 and 2015 by the renovated PRO and penstocks, flushing $10 \%$ of the volume that was removed from the reservoir during the 38 years of dredging. During the 2013 typhoon Soulik alone, the sediment sluicing operations (Figure 4d) produced a desilting efficiency, calculated as the ratio of sediment outflow to sediment inflow, of approximately $35 \%\left(2.9 \mathrm{Mm}^{3}\right)$, by the spillway, tunnel spillway, Shihmen irrigation channel, power plant penstock, and renovated PRO and penstocks.

In addition to these renovations, engineers have undertaken physical and numerical modeling to inform design of a sediment bypass from the river upstream of the reservoir and desilting tunnels from the reservoir itself [39-42]. The Amuping desilting tunnel will divert discharge and sediment from the midpoint of the reservoir into a $3.7 \mathrm{~km}$-long tunnel with a gradient of $2.86 \%$ to transport 0.084-0.104 mm sized sediment [43]. During low water levels, sediments will be hydraulically dredged from the reservoir and transported, through four pipelines embedded with the tunnel, to a temporary sediment storage site downstream of the reservoir, from which sediment will be flushed during high flows. At very low water levels, mechanically dredged material will be trucked through the tunnel to the temporary storage site. After completing the Amuping desilting tunnel, WRA plans to construct the Dawanping desilting tunnel to vent turbidity currents through two 10-m-diameter steel pipes via an intake structure, a $0.9-\mathrm{km}$ tunnel, and two outlets, rejoining the river one $\mathrm{km}$ downstream of the dam. The gradient of the desilting tunnel is designed to be $2.4 \%$, and sediments of grain size less than $0.0625 \mathrm{~mm}$ are expected to move through the tunnel. The construction cost of Amuping is estimated at $\$ 133$ M USD, that of Dawanping about \$160 M USD [29], and they are expected to remove about $1.35 \mathrm{M}$ tonnes of sediment per year, representing approximately $39 \%$ of the mean annual sediment inflow.

The passage of sediment through the bypass and desilting tunnels is expected to result in increased sediment concentrations and up to $2 \mathrm{~m}$ aggradation of the bed downstream [41,42]. Operation of the sediment desilting tunnel is complicated by the needs of downstream water users for diverting clear water. Periodic pulses of turbidity from a sediment desilting tunnel system will interfere with the current diversion practices, preventing diversions for days at a time [42]. To solve this problem, WRA constructed off-channel water storage facilities with capacity of $4.92 \mathrm{Mm}^{3}$ in 2016 to provide water supply of $24,000 \mathrm{~m}^{3} /$ day during normal operation and $800,000 \mathrm{~m}^{3} /$ day for 6.2 days during the periods when diversions are curtailed from the river. 


\subsection{Case Study 2: Ronghua}

Ronghua Dam was constructed in 1983, with the design life of 25 years, as one of the over 120 sabo dams to trap sediment on Dahan River that would otherwise be transported to the Shihmen Reservoir downstream. Ronghua is an $82 \mathrm{~m}$-high concrete arch dam, with initial capacity of $12.4 \mathrm{Mm}^{3}$. As of 2003, the reservoir was almost filled with sediment and remaining capacity as of 2014 was less than $1 \%$ (Figure 2b). Abrasion of the structure from sediment passing over the spillway required engineering actions, at a cost of approximately \$0.07 M USD [44], to protect the dam from failure. In 2009, concrete was added to the downstream dam face, abutments, and to fill scour holes in the dam foundation. In 2011, a new grade control structure was constructed $50 \mathrm{~m}$ downstream of the dam to replace the previous "defense dam," designed to control grade and to pond water to form a water cushion to break the force of water falling from the dam, which was damaged from abrasion by passing bedload.

In addition to sediment trapping, Ronghua also generates hydropower by a $4.7-\mathrm{km}$ water intake tunnel for the Yixing power plant, located approximately $8 \mathrm{~km}$ downstream, for annual generation capacity of 0.2 billion $\mathrm{kWh}$ and an annual hydropower benefit of about \$6.5 M USD [45]. Maintaining the power generation has been achieved by opening a $2.5 \mathrm{~m} \times 2.5 \mathrm{~m}$ gate in the left abutment of the Ronghua dam to flush a small amount of sediment, at a design discharge of $49 \mathrm{~m}^{3} / \mathrm{s}$, to prevent sediment from entering the hydropower intake [45].

Other sediment management approaches considered by the WRA include hydraulic dredging, mechanical removal, construction of a sediment bypass system to divert bedload, with the estimated costs ranging from $\$ 6.7 \mathrm{M}$ to $50 \mathrm{M}$ USD. However, owing to issues with road access, traffic impacts, and the dam having already exceeded its design life, none of the strategies have been implemented.

\subsection{Case Study 3: Wujie}

At $58 \mathrm{~m}$ high, Wujie Dam impounds the Choshui River and Wanta Creek, with designed storage of $14 \mathrm{Mm}^{3}$. Its primary objective is to divert flow into a 15.2-km-long tunnel to Sun Moon Lake, one of Taiwan's most popular recreational areas (storage capacity $150 \mathrm{Mm}^{3}$ ), generating $7600 \mathrm{kWh}$ /year. Due to the high sediment yield of Choshui ("turbid water") River, the reservoir almost filled six years after its completion in 1934 (Figure 2c).

To maintain Wujie Dam's function of supplying water to Sun Moon Lake, Taipower Company has been operating drawdown flushing using the original flood gates during flood season (Figure 4e) two to three times annually since 1978. The operation rules [46] prescribe that drawdown should be operated 1) during the first flood of the season that is higher than $80 \mathrm{~m}^{3} / \mathrm{s}, 2$ ) when suspended sediment concentrations are over $44,000 \mathrm{ppm}$, and 3) when the elevation of the sedimentation surface is less than $2 \mathrm{~m}$ from the intake invert. For downstream safety, to avoid abrupt flow increases, releases from the dam are prescribed to be no more than $50 \%$ greater than the inflow. The flushing regime protects the entrance of the water intakes from sedimentation and increases the remaining storage from $300,000 \mathrm{~m}^{3}$ to $1 \mathrm{Mm}^{3}$ ( $2 \%$ to $7 \%$ of the original storage capacity) per year [47].

However, reservoir drawdown can bring the coarser material to the dam, resulting in severe abrasion of the water intake tunnels, requiring frequent repairs. To relieve pressure on this tunnel, a new $16.5-\mathrm{km}$ long, $5 \mathrm{~m}$ wide tunnel was constructed in 2006, which is operated jointly with the old 15.2-km tunnel.

\subsection{Case Study 4: Jensanpei Reservoir}

Jensanpei Reservoir was constructed in 1938 on the Chishui River to supply water for processing sugar cane. Of the original $7 \mathrm{Mm}^{3}$ capacity, $4.3 \mathrm{Mm}^{3}$ (about 60\%) was lost to sedimentation by 1955 (Figure 2d). To regain reservoir capacity and prolong the life of the reservoir, a sluicing gallery was constructed in 1955 through the right abutment of the dam, with a 1.5-m diameter horizontal tunnel and vertical tower to flush sediment from the reservoir. Because the reservoir's purpose was solely to provide water for processing sugar cane, which is harvested between November and April, water was 
not needed from May through October. Thus, it was possible to draw the reservoir down and keep the sluicing gallery open from May until July, so that the first flows of the rainy season would carry their sediment flows through the reservoir and dam and erode prior deposits. Afterward, the sluice gates were closed to impound water over the rest of the rainy season (Figure 5a, [22]). Through 2008, the sluicing system had worked well, maintaining reservoir capacity roughly at 1955 levels, as illustrated in capacity data (Figure $2 \mathrm{~d}$ ).

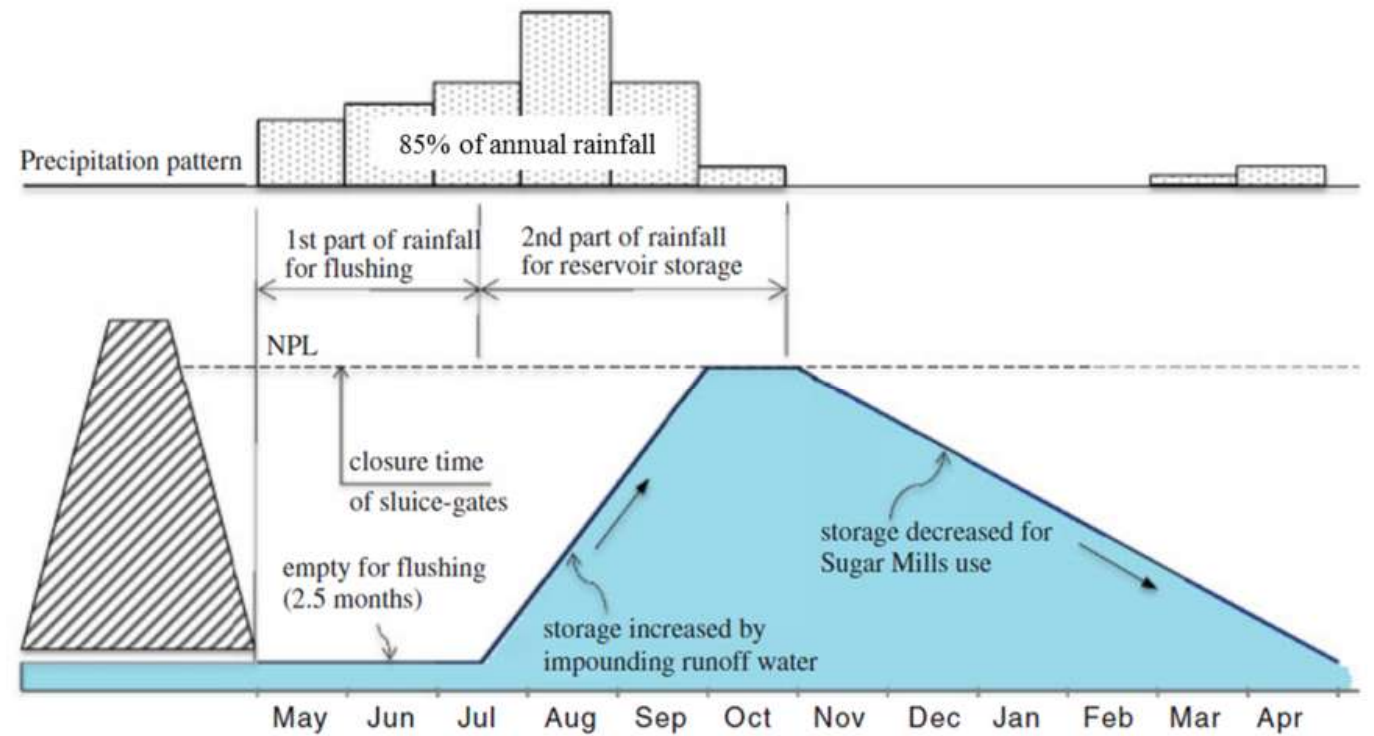

A) Jensanpei Reservoir

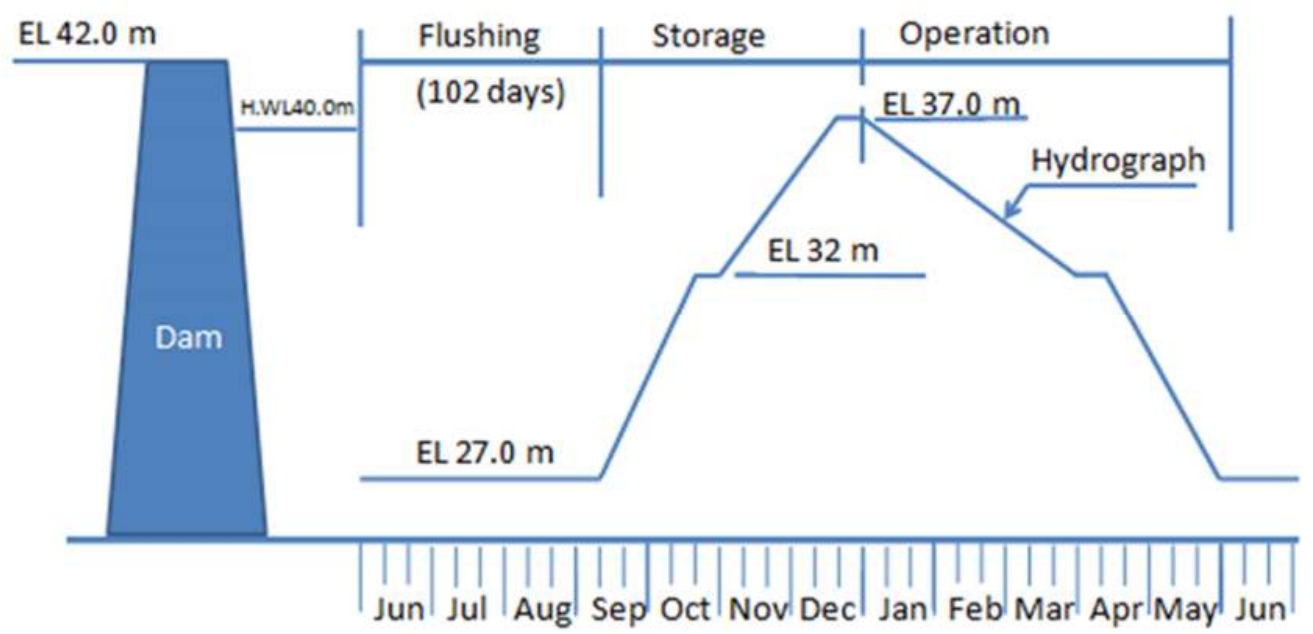

B) Agongdian Reservoir

Figure 5. Operational pattern of (A) Jensanpei (Kondolf et al. [18]; updated from Hwang [22]) and (B) Agongdian reservoirs (Reproduced from Hwang [22]).

The single purpose operation of Jensanpei Reservoir facilitated its sustainable operation. However, Taiwan Sugar Corporation, owner of the dam, reduced the number of its sugar mills from 30 in 1960 to 10 in 2000, and closed the rest by 2010. Thus, other uses of Jensanpei Reservoir were developed, including tourism around the reservoir, for which managers constructed guest cottages and a children's amusement park and landscaped the lake margins. Reservoir drawdown exposed the muddy reservoir 
bottom for two to three months each year, including part of summer vacation season. The exposed mud conflicted with the reservoir's use for tourism. This conflict, combined with drought-induced emphasis on storing water, led the managers to decide against emptying the reservoir from 1998 to 2012. By 2012, a further $22 \%$ of the reservoir's storage capacity (for a total of $78 \%$ ) had been lost to sedimentation, motivating a decision to resume sediment flushing (Figure $2 \mathrm{~d}$ ). The sluice gate, which had become nonfunctional due to sedimentation and lack of maintenance, was repaired, but since then, drawdown flushing has been implemented only once, during a typhoon in 2013. However, the 2013 flushing was conducted on an ad-hoc basis, not based on an operation rule, nor involving field monitoring studies, experiments, or analysis to assess flushing efficiency for different operating schedules (e.g., to determine if flushing could be achieved with a shorter or less frequent schedule).

\subsection{Case Study 5: Agongdian Reservoir}

The $31 \mathrm{~m}$ high dam impounding Agongdian Creek was constructed in 1953 for flood regulation and to store water for irrigation and municipal supply. By 2000, over $53 \%$ of its initial storage capacity $\left(36.7 \mathrm{Mm}^{3}\right.$ ) had been lost to sedimentation (Figure 2e), leaving only $17.2 \mathrm{Mm}^{3}$ capacity. Sediments were predominantly silts and clays, with median grain sizes ranging from 0.0056 to $0.0494 \mathrm{~mm}$ across the reservoir [48] and on the order of 0.0034 to $0.09 \mathrm{~mm}$ at the spillway entrance [49].

To address the sedimentation as well as water supply, a number of physical models and numerical simulations [30-33] were conducted. The final set of strategies implemented in 1997 and completed in 2005 included: (1) a transbasin water diversion to bring water from Qishan River during drawdown period (cost \$130 M USD), (2) spillway reconstruction to lower a $2.8 \mathrm{~m}$ diameter sluice gate by $7.5 \mathrm{~m}$, (3) pipeline reconstruction to increase the sluicing capacity, (4) mechanical excavation and dredging of $11.6 \mathrm{Mm}^{3}$ of deposited silt (\$190 M USD), and (5) construction of check dams and soil conservation works in the basin upstream (\$4 M USD).

To maintain the capacity recovered at such cost, the reservoir's operational pattern was modified (Figure 5b). The reservoir is drawn down and the sluicing gallery is kept open during the first flows of the rainy season from 1 June to 10 September, unless there is a drought warning. The sluice gates are then closed to impound water for the remaining (11 September to 31 May) season. The flushing system initially worked well in maintaining reservoir capacity roughly at 2005 levels, with flushing efficiency as high as approximately $80 \%$ during some events. The annual sedimentation rate in the period from 2005 to 2015 was approximately $0.21 \mathrm{Mm}^{3}$, half of that $\left(0.42 \mathrm{Mm}^{3}\right)$ before the sediment management was conducted (1953-1998).

However, due to pressure from tourism uses of the reservoir, the operational rule was further modified to allow storing water up to $3 \mathrm{~m}$ deep when there is no typhoon [50]. The not-entirely empty flushing resulted in decreased efficiency to only approximately $50 \%$ for some events [51]. Completed in 2005 , the infrastructure changes restored $3 \%$ of the reservoir capacity to $18.4 \mathrm{Mm}^{3}$, but $6 \%$ capacity $\left(2.1 \mathrm{Mm}^{3}\right)$ has since been lost over the past decade despite the sediment management strategies (Figure 2e).

\subsection{Case Study 6: Zengwen Reservoir}

The 133 m high Zengwen Dam was constructed on the Zengwen River in 1973. With initial capacity of $748.4 \mathrm{Mm}^{3}$, Zengwen Reservoir is the largest reservoir in Taiwan, supplying water for irrigation $(85,424 \mathrm{ha})$, as well as secondarily meeting municipal and industrial demands. The reservoir sediment management is a challenge due to the great variation of seasonal and annual rainfall in the catchment. About $90 \%$ of the annual rainfall is concentrated in the wet season from May through October, and only $10 \%$ is distributed throughout the rest of the year. Approximately $167 \mathrm{Mm}^{3}$ of sediment accumulated in the reservoir between 1973 and 2008 (Figure 2f), for an average annual sedimentation rate of $4.7 \mathrm{Mm}^{3}$ and a net loss in capacity of $37 \%$ by 2015 .

To manage the high sediment loads to the reservoir, from 1968 to 1990, more than \$40 M USD was spent on construction of sabo dams, hillside erosion control measures, including geogrids and tree 
planting [34]. Six large sabo dams (Daban, Daderan, Leryeh, Fushan, Dapu, and Lijia), constructed from 1979 to 1990 with designed capacity ranging from 0.9 to $2.8 \mathrm{Mm}^{3}$, had filled with sediment by 2000 , for a total of about $13 \mathrm{Mm}^{3}$ of sedimentation in the sabo dams alone [34].

In August 2009, typhoon Morakot deposited approximately $91 \mathrm{Mm}^{3}$ in the reservoir in a single event, motivating a renewed effort for sediment management. Since 2009, the WRA mechanically removed $4.6 \mathrm{Mm}^{3}$ of coarse sediment from the Dapu reservoir, the most downstream of the sediment retention dams, from the upstream portion of the Zengwen Reservoir delta, and from the intervening channel. While some of these removed sediments can be sold for commercial use for a modest return $\left(\$ 0.5 \mathrm{USD} / \mathrm{m}^{3}\right)$, others were of limited value due to weak demand for aggregate. Between 2012 and $2015,2 \mathrm{Mm}^{3}$ of finer-grained sediment was removed by hydraulic dredging from lower Zengwen Reservoir at a cost of \$17 M USD.

In addition, structural modifications were made. After typhoon Morakot, the bed of the reservoir aggraded with sediment up to elevation $177 \mathrm{~m}$, much higher than the invert elevation (EL $154 \mathrm{~m}$ ) of the intake, and began interfering with the operation of the regulating PRO. In 2010, WRA began using the PRO to sluice during periods when power production was interrupted by high turbidity (greater than 5500 NTU). In 2012, a PRO renovation was implemented by replacing the original Howell-Bunger valve with a jet flow gate and construction of three tunnels for future maintenance, at a cost of $\$ 18 \mathrm{M}$ USD. Using the PROs, a total of $1.8 \mathrm{Mm}^{3}$ of sediment was sluiced

\section{Synthesis: Needs for and Barriers to Sustainable Reservoirs}

As is the case for many locations around the world with highly seasonal precipitation and erodible landscapes, the ability to store water to meet demands, produce hydropower, and regulate floods is threatened by reservoir sedimentation. A number of options are available for managing sediment in reservoirs, each with important tradeoffs and limitations (Table 1). For example, dredging is commonly applied in reservoirs that lack low-level outlets but is expensive on a unit basis and generally not effective at maintaining reservoir capacity over the long term. Alternately, flushing is highly effective in restoring reservoir capacity but requires that a dam has low level outlets, narrow and steep morphology, no carryover storage, and low capacity to inflow ratios [52]. Given the high sediment yields and rapid sedimentation rates, a number of strategies for managing sediment have been implemented in Taiwan, and these can offer insights into the effectiveness, tradeoffs, and barriers of various approaches. For example, sediment sluicing in Taiwan has been shown to discharge only $30-40 \%$ of incoming sediment, meaning that other complementary methods will be required. Thus, dredging continues to be an essential component to prolong reservoir life.

When viewing the six case study reservoirs through the perspective of the sediment management framework of Annandale et al. [8] (Table 5), we found that some sediment management strategies were more commonly applied, such as reducing sediment yield from the catchment, sediment trapping above the reservoir (i.e., sabo dams), modifying dam operating rules, and hydraulic scour near outlets. However, these practices represent the 'low-hanging fruit', generally characterized by low capital costs but also of limited effectiveness in maintaining and/or restoring reservoir capacity. In contrast, some of the most effective sediment management strategies were not considered (i.e., decommissioning infrastructure) or implemented at only two of the sites (sediment bypass and sediment pass-through). Perhaps more striking was the lack of sediment management plans and monitoring for all but two of the sites. While intakes and hydraulic structures were modified or considered to be modified at four of the six projects, only two of those renovated projects had comprehensive plans that place those renovations within the longer-term context of sediment management. For instance, a comprehensive plan at Shihmen was developed to identify the management strategies that may be used over time to combat sedimentation for sustainable reservoir sediment management (Figure 3). However, there is no 'end-of-project' scenario for any of the sites. 
Table 5. Sediment management framework, including (1) sediment management alternatives and (2) selected checklist question, adapted from Annandale et al. [8]

\begin{tabular}{|c|c|c|c|c|c|c|c|c|}
\hline & & & Shihmen & Ronghua & Wujie & Jensanpei & Agongdian & Zengwen \\
\hline \multirow{12}{*}{$\begin{array}{l}\text { Have the sediment } \\
\text { management alternatives been } \\
\text { considered/implemented? }\end{array}$} & \multirow{2}{*}{$\begin{array}{l}\text { Reduce sediment yield from } \\
\text { upstream }\end{array}$} & Reduce sediment production & $\bullet$ & $\bullet$ & $\bullet$ & $\bullet$ & $\bullet$ & $\bullet$ \\
\hline & & Sediment trapping above reservoir & $\bullet$ & $\bullet$ & $\bullet$ & $\mathrm{x}$ & $\bullet$ & $\bullet$ \\
\hline & \multirow{2}{*}{ Route sediments } & Sediment bypass & $\bullet^{1}$ & (0) & $\mathrm{x}$ & $\mathrm{x}$ & $\bullet^{2}$ & (0) \\
\hline & & Sediment pass-through & $\bullet$ & (0) & $\mathrm{x}$ & $\mathrm{x}$ & $\bullet$ & $\bullet$ \\
\hline & \multirow{3}{*}{$\begin{array}{l}\text { Remove or redistribute } \\
\text { sediment deposits }\end{array}$} & Mechanical excavation & $\bullet$ & $\mathrm{x}$ & $\mathrm{x}$ & $\bullet^{3}$ & $\bullet^{3}$ & $\bullet$ \\
\hline & & Modify operating rule & $\bullet$ & $\bullet$ & $\bullet$ & $\bullet$ & $\bullet$ & $\bullet$ \\
\hline & & Hydraulic scour & $\mathrm{x}$ & $\bullet^{4}$ & $\bullet^{4}$ & $\bullet$ & $\bullet$ & $\mathrm{x}$ \\
\hline & \multirow{5}{*}{ Adaptive strategies } & Reallocate storage & $\mathrm{x}$ & $\mathrm{x}$ & $\mathrm{x}$ & (0) & $\mathrm{x}$ & $\mathrm{x}$ \\
\hline & & Modify facility to handle sediment & $\bullet$ & ( & $\mathrm{x}$ & $\mathrm{x}$ & $\bullet^{5}$ & $\bullet^{6}$ \\
\hline & & Raise dam to increase volume & $\mathrm{x}$ & $\mathrm{x}$ & $\mathrm{x}$ & $\bullet$ & $\mathrm{x}$ & $\bullet$ \\
\hline & & Water loss control and conservation & $\bullet^{7}$ & $\mathrm{x}$ & $\mathrm{x}$ & $\mathrm{x}$ & $\mathrm{x}$ & $\mathrm{x}$ \\
\hline & & Decommission infrastructure & $\mathrm{x}$ & $\mathrm{x}$ & $\mathrm{x}$ & $\mathrm{x}$ & $\mathrm{x}$ & $\mathrm{x}$ \\
\hline \multicolumn{3}{|c|}{$\begin{array}{l}\text { Has a sustainable sediment management plan been developed to identify the management strategies that may be } \\
\text { used over time to combat sedimentation? }\end{array}$} & $\bullet^{8}$ & $\mathrm{x}$ & $\mathrm{x}$ & $\mathrm{x}$ & $\mathrm{x}$ & $\bullet$ \\
\hline \multicolumn{3}{|c|}{ Have or Will measures be implemented to enhance sustainability with implementation schedule? } & $\bullet^{8}$ & $\mathrm{x}$ & $\mathrm{x}$ & $\mathrm{x}$ & $\mathrm{x}$ & (0) \\
\hline \multicolumn{3}{|c|}{$\begin{array}{l}\text { Are the dam, intakes, and other hydraulic structures designed to facilitate implementation of future sediment } \\
\text { control measures? }\end{array}$} & $\bullet^{9}$ & (0) & $\mathrm{x}$ & $\bullet^{9}$ & $\bullet$ & $\bullet$ \\
\hline \multicolumn{3}{|c|}{$\begin{array}{l}\text { Has the need for a real-time sediment monitoring system and sediment-guided operation been evaluated, and if } \\
\text { needed has it been incorporated into the project? }\end{array}$} & $\bullet$ & $\mathrm{x}$ & $\mathrm{x}$ & $\mathrm{x}$ & $\mathrm{x}$ & $\bullet$ \\
\hline \multicolumn{3}{|c|}{ Is there a viable end-of-project scenario? } & $\mathrm{x}$ & $\mathrm{x}$ & $\mathrm{x}$ & $\mathrm{x}$ & $\mathrm{x}$ & $\mathrm{x}$ \\
\hline \multicolumn{3}{|c|}{$\begin{array}{l}\text { Has a reservoir monitoring program been developed that includes a standardized bathymetric protocol starting } \\
\text { with the first bathymetric survey soon after initial filling? }\end{array}$} & $\bullet$ & $\mathrm{x}$ & $\mathrm{x}$ & $\mathrm{x}$ & $\bullet^{10}$ & $\bullet$ \\
\hline \multicolumn{3}{|c|}{ Has a monitoring program for impacts downstream of the dam been designed? } & $\bullet$ & $\mathrm{x}$ & $\mathrm{x}$ & $\mathrm{x}$ & (2) & $\bullet$ \\
\hline
\end{tabular}

-: Considered and implemented; (O): Only considered; x: Not considered. ${ }^{1}$ Amuping desilting tunnel. ${ }^{2}$ Flood bypass tunnel to Chishan River. ${ }^{3}$ Not annually. ${ }^{4}$ Maintain hydropower function. ${ }^{5}$ Sluice gate reconstruction. ${ }^{6}$ Permanent river outlet or power plant penstocks renovation. ${ }^{7}$ Off-channel water storage facilities and surface intake shaft system. ${ }^{8}$ Refer to Figure $3 .{ }^{9}$ After modification or renovation. ${ }^{10}$ After reservoir renovation. 


\subsection{Barriers to Sustainable Reservoirs}

Among the study sites discussed, Shihmen and Zengwen are the most important reservoirs, supplying water to more than $25 \%$ and $40 \%$ of the water needed for the island's northern and southern regions, respectively. However, despite earlier studies highlighting the need for sustainable management of sediment in reservoirs [22], sedimentation was not taken seriously in these reservoirs until each lost a large fraction of its total capacity during a single typhoon-Typhoon Aere in 2004 for Shihmen and Morakot in 2009 for Zengwen. Reservoir sedimentation has been similarly ignored in the US, at least until a reservoir fills with sediment and becomes a liability to the owners and downstream residents, and then the focus is usually on the individual dam only, not the broader problem.

For Ronghua and Wujie, the two reservoirs with no remaining capacity, the originally stated design lives were short. For instance, Ronghua was expected to fill with sediment within 25 years. Since the reservoir filled, it has functioned mainly for power generation, no longer storing sediment to reduce sediment delivery to Shihmen Reservoir downstream. For dams whose primary objective was sediment retention, the expected timeframe for their benefit was short. Moreover, sediment-filled dams can either fail catastrophically [36,37] or become expensive engineering problems upon decommissioning (Table 6, [53-55]), creating hazards and burdens for future generations. Reservoir sedimentation demonstrates the critical need to take a full life cycle approach during design and construction of any dam, accounting for decommissioning and sediment management at the end of the project life [10].

For Agongdian and Jensanpei, the two reservoirs practicing drawdown flushing to facilitate sustainable operation, conflicts with competing use of the reservoir for tourism led managers to decide against emptying the reservoirs. Education of the public on the importance of sediment flushing may help reduce conflicts between recreational and sedimentation operations. For example, a visitor center could display models of the catchment, explain fundamental principles of erosion, sediment transport, and deposition, and could explain the operation of the sediment flushing system. A physical model could be constructed in which the effects of flushing could be demonstrated. During the drawdown period, amusement parks and other attractions can still function, and the accommodations could be discounted during this period as a further incentive to tourists. However, public education must be complemented by strong leadership from reservoir managers and politicians to ensure that the key benefits of flood regulation and water supply are not compromised in the interest of promoting tourism.

As demonstrated in the case studies reviewed, a number of technical barriers exist for reservoir sediment management. For example, mechanical and hydraulic dredging are limited by insufficient temporary sites for storing dredged sediments, the difficulty in trucking of mechanically removed materials, and the limited demand for use of dredged materials in construction. Similarly, check dams constructed upstream of large reservoirs create multiple small sediment-filled reservoirs, some located in sites inaccessible to mechanical removal, and do not offer a safe or long-term means for addressing reservoir sedimentation. Alternately, a number of the more effective sediment management techniques to pass sediment downstream (e.g., drawdown flushing, sluicing, venting turbidity currents) require large low-level outlets, which can be expensive or technically infeasible to retrofit into existing dams. Sediment bypass tunnels can be effective but are typically very costly. The sediment pass-through methods also require technical understanding, data, and models to be effectively operated. For instance, understanding the behavior and interactions between hydraulics and sediment (e.g., tunnel slope, inflow and conditions, sediment characteristics, maintenance requirements) in sediment bypass tunnels is needed to avoid the need for frequent maintenance as bedload abrades the concrete [56]. Some of these techniques also require real-time operations, such as the opening of outlets when density currents are detected in the inflowing river.

The case studies show that the strategies being used at most sites (e.g., mechanical dredging, hydraulic dredging) are commonly not the most effective or efficient to restore reservoir capacity, and the available information suggests that short-term economic barriers may be at least partly responsible for their use in lieu of more efficient approaches that require a larger up-front capital investment. The commonly used strategies (e.g., dredging) are relatively easy to implement, have low capital 
investment requirements, and offer potential value added from selling coarse aggregate for construction (at least when the material can be sold). However, the effectiveness of dredging even to maintain reservoir capacity relative to annual sediment inflow is very low. For instance, in Shihmen Reservoir, approximately \$160 M USD was spent on hydraulic dredging over 31 years (1985 to 2015), resulting in a removal of only $8.1 \mathrm{Mm}^{3}$ of sediment at a unit cost of approximately $\$ 20 \mathrm{USD} / \mathrm{m}^{3}$. In contrast, the PRO modifications, spillway tunnel, and turbidity venting renovation projects effectively removed about $12.6 \mathrm{Mm}^{3}$ of sediment in a period of 10 years (2005 to 2015), with a total initial engineering cost of about $\$ 67 \mathrm{M} \mathrm{USD}$, for a unit cost of about $\$ 5 \mathrm{USD} / \mathrm{m}^{3}$. Thus, the infrastructure retrofits had a much higher economic efficiency than did the hydraulic dredging. Moreover, time horizons of management are also an important metric in comparing sediment management strategies. Dredging at Shihmen took 31 years to remove the same amount of sediment as the PRO modifications removed in only 8 years. The cost of modifications to the power plant (\$29 M USD) at Shihmen to facilitate turbidity current venting, calculated over a 25-year design life of the tunnel, yielded a smaller unit cost for sediment removal $\left(\$ 3 \mathrm{USD} / \mathrm{m}^{3}\right)$ than did hydraulic dredging $\left(\$ 20 \mathrm{USD} / \mathrm{m}^{3}\right)$. Desilting tunnels also have high economic efficiency compared to traditional dredging. The planned Amuping Desilting Tunnel will require an initial investment of \$133 M USD, but in 25 years of operation is expected to remove $0.64 \mathrm{Mm}^{3}$ of sediment annually [43]. Thus, its total cost is \$33 M USD less than hydraulic dredging to remove the same volume of material, making it $\sim 250 \%$ more efficient than hydraulic dredging. While these sediment removal innovations have a high initial capital cost, they are more cost effective over the long term than traditional dredging.

Classifying the conflicts associated with sustainable sediment management at the Taiwan case studies highlights how social, technical, environmental, and economic barriers all inhibit effectively addressing sedimentation in reservoirs (Table 7). Social barriers can be local (e.g., traffic concerns, tourism impacts, flood hazards) to global (e.g., design-life engineering paradigm, disregarding intergenerational equity). Among them, social concern about increased flood hazard risk due to aggradation downstream is also a technical issue. While the evaluation of increased sediment concentrations and aggradation of the bed downstream due to sediment passed through the bypass and desilting tunnels were conducted for Shihmen [41,42], there were very few systematic evaluations for other sites. A variety of technical concerns may emerge at any individual project. The methodological and financial challenges associated with monitoring sediment inflows for sediment management was the most common technical barrier we identified for the our Taiwan case studies in Taiwan, though methods for monitoring sediment are well established [57]. The loss of water supply associated with sediment flushing and sediment pass-through was also a common technical barrier across our case studies, as it has been reported for projects globally [52]. The primary environmental impact of sediment management is associated with elevated turbidity, though it was identified as a concern only at two of the sites, and the literature on this impact is still immature. For instance, large pulse releases of sediment during flushing operations can impact downstream aquatic organisms through abrasion, burial, and in cases of organic sediments, anoxia [58,59]. Besides, dredging is known to impact aquatic organisms in the reservoirs in a variety of adverse ways $[60,61]$ that range from direct mortality over the short term to transgenerational effects over the long term. However, we did not evaluate the ecological implications of different sediment management techniques, though a comprehensive analysis of this topic is needed. Engineering and ecological research could evaluate operational and mechanical sediment management based on deviations from background concentrations or behavioral or toxicity thresholds for aquatic organisms (e.g., [62]). The most obvious economic impacts were associated with the capital costs of modifying water infrastructure to accommodate sediment flushing, but ancillary impacts, such as foregone hydropower revenue, may also pose real barriers to implementing some of the most sustainable sediment management solutions. It is worth noting that the most commonly identified conflicts (e.g., design-life, capital costs, monitoring, impacts to water supply; Table 7) tended to be addressed by more short-term strategies (e.g., mechanical dredging, check dams) over the long-term solutions (e.g., infrastructure retrofits). 
Table 6. Dam decommissioning costs ([55-57]).

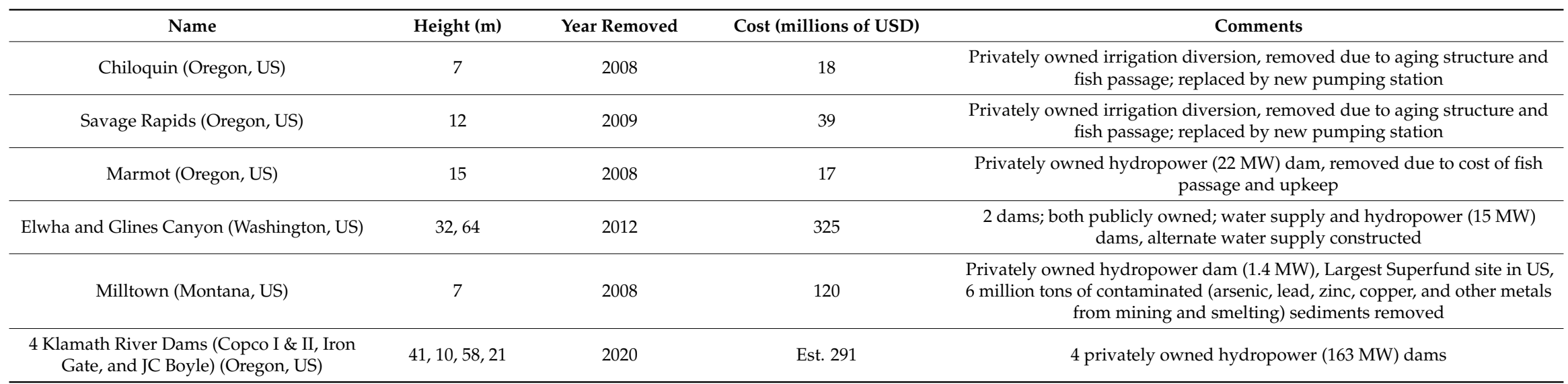


Table 7. Barriers associated with sustainable sediment management at the Taiwan case studies.

\begin{tabular}{|c|c|c|c|c|c|c|c|}
\hline Barrier Type & Conflicts & Shihmen & Ronghua & Wujie & Jensanpei & Agongdian & Zengwen \\
\hline \multirow{6}{*}{ Social } & Aesthetic considerations for tourism & $\mathrm{x}$ & $\mathrm{x}$ & $\mathrm{x}$ & $\bullet$ & $\bullet$ & $\mathrm{x}$ \\
\hline & Engineering standards of practice that promote the design life paradigm & $\bullet$ & $\bullet$ & $\mathrm{x}$ & $\mathrm{x}$ & $\bullet$ & $\bullet$ \\
\hline & Failure to put sedimentation in long-term and larger spatial scale context & & $\bullet$ & $\bullet$ & $\bullet$ & $\bullet$ & $\bullet$ \\
\hline & Failure to account for intergenerational equity & $\bullet$ & $\bullet$ & $\bullet$ & $\bullet$ & $\bullet$ & $\bullet$ \\
\hline & $\begin{array}{l}\text { Concerns about increased flood hazard risk due to aggradation if years of accumulated } \\
\text { sediment are suddenly released and deposited in the downstream river bed. }\end{array}$ & $\bullet$ & $\mathrm{x}$ & $\mathrm{x}$ & $\mathrm{x}$ & $\bullet$ & $\bullet$ \\
\hline & Traffic concerns when transporting mechanical sediment removal & $\bullet$ & $\bullet$ & $\mathrm{x}$ & $\mathrm{x}$ & $\mathrm{x}$ & $\bullet$ \\
\hline \multirow{4}{*}{ Technical } & Short term storage site for removed sediment & $\bullet$ & $\bullet$ & $\mathrm{x}$ & $\mathrm{x}$ & $\mathrm{x}$ & $\bullet$ \\
\hline & Loss of water supply associated with flushing and pass-through operations & $\bullet$ & $\bullet$ & $\mathrm{x}$ & $\mathrm{x}$ & $\bullet$ & $\bullet$ \\
\hline & $\begin{array}{l}\text { Potential impacts of sediment-laden water to downstream users (e.g., drinking water and } \\
\text { irrigation intakes), which cannot handle large sediment loads. }\end{array}$ & $\bullet$ & $\mathrm{x}$ & $\mathrm{x}$ & $\mathrm{x}$ & $\mathrm{x}$ & $\bullet$ \\
\hline & Cost of monitoring equipment is high and accurate sediment monitoring is difficult. & $\bullet$ & $\bullet$ & $\bullet$ & $\bullet$ & $\bullet$ & $\bullet$ \\
\hline Environmental & $\begin{array}{l}\text { Potential for increased magnitude and duration of downstream turbidity to negatively } \\
\text { impact aquatic organisms }\end{array}$ & $\bullet$ & $\mathrm{x}$ & $\mathrm{x}$ & $\mathrm{x}$ & $\mathrm{x}$ & $\bullet$ \\
\hline \multirow{2}{*}{ Economic } & Concern of high initial cost of dam retrofit and new facility construction & $\bullet$ & $\bullet$ & $\mathrm{x}$ & $\mathrm{x}$ & $\bullet$ & $\bullet$ \\
\hline & Resistance from power producers to impact the power pool & $\mathrm{x}$ & $\bullet$ & $\bullet$ & $\mathrm{x}$ & $\mathrm{x}$ & - \\
\hline
\end{tabular}

๑: Present; $x$ : Not present. 


\subsection{Suitability of Techniques}

As noted by White [1], the characteristics of a site can strongly influence the suitability of different sediment management techniques. For example, despite its effectiveness, drawdown flushing during the flood and non-flood season has been implemented at relatively few sites around the world-and at only two of the study sites discussed herein-due to local operational constraints. Drawdown flushing of sediment during the non-flood season is limited to hydrologically small reservoirs, where the ratio of storage capacity to mean annual runoff (Table 3) does not exceed a certain range of values $[1,10,13,18]$. For instance, Kondolf et al. [18] suggested that the ratio should not exceed $4 \%$ for flushing to be successful. In hydrologically "large" reservoirs, where drawdown is not an option, major infrastructure modifications may be needed to manage sediment by venting turbidity currents or bypassing incoming sediment.

Similarly, site conditions influence the suitability of other sediment management strategies. Bypass channels require certain geological conditions at the site to be effective [14]. Bypasses are best-adapted to situations where the geometry of the river and reservoir make possible a steeper short-cut route for the bypass channel, such as where the reservoir occupies a river bend. As the feasibility study of constructing sediment bypass at one of the study sites (Zengwen [63]) showed, the unfavorable geometry, the high construction cost, and the engineering difficulty make the construction of sediment bypass unlikely. Furthermore, as a relatively new technique, understanding the behavior and interactions between hydraulics and sediment (e.g., tunnel slope, inflow and conditions, sediment characteristics, maintenance requirements) in sediment bypass tunnels is needed to avoid the need for frequent maintenance as bedload abrades the concrete [56].

\section{Conclusions}

Reservoirs play a critically important role in providing water supply for human uses, especially in regions with highly variable precipitation, where water must be stored during months and years of abundance for using in dry seasons and drought years. However, sedimentation will continue to limit the benefit of storage reservoirs, as well as increase risk for aging infrastructure. The situation of dams filling with sediment, and a risk of failure and downstream release of decades of accumulated sediment, is not unique to Taiwan. By virtue of the unusually high sediment yields of the Central Range of Taiwan, the problems of reservoir sedimentation are confronting river managers sooner in Taiwan than elsewhere. However, similar situations can be found in other countries, such as China, Japan, Switzerland, and the US, and will become increasingly common globally as reservoirs fill over time.

The rapid rate of sediment deposition during recent typhoons and the expectations for more intense typhoons under changing climatic conditions underline the urgent need to find and implement better forms of sediment management in landscapes with high sediment yields and high energy rivers. The failure of Barlin Dam illustrates the pitfalls of using small upstream reservoirs to reduce sediment delivery to a larger downstream reservoir. The filling and failing of dams highlights the urgent need to develop and test strategies to address sediment-impacted structures and to expand the scientific basis for establishing more sustainable solutions for sediment management. These solutions should include a requirement to plan for the costs of sediment management in the design and economic analysis of new dams.

These case studies from Taiwan highlight the social barriers to reservoir sustainability, including the crisis-response approach to addressing sedimentation and the low priority for sediment management relative to competing objectives for reservoirs. Technical and economic barriers also exist, driven primarily by the engineering challenges and costs of retrofitting existing dams with new infrastructure to flush or bypass sediment. For new and existing dams, sediment management strategies should be evaluated on the basis of cost and efficiency rather than continuing to dredge because of its technical simplicity. Finally, a number of site conditions, such as road access or valley geometry, may impact the suitability of any given sediment management practice at a site. A systematic approach for evaluating the social, economic, ecological, and engineering tradeoffs of sediment management could facilitate this critical aspect of sustainable water resources. Ultimately, for many 
areas of the world characterized by high sediment yields, a suite of sediment management practices may be necessary.

Author Contributions: Conceptualization, H.-W.W. and M.K.; Methodology, H.-W.W., M.K. and D.T.; Validation, M.K. and D.T.; Formal Analysis, H.-W.W. and W.-C.K.; Investigation, W.-C.K.; Data Curation, W.-C.K.; Writing-Original Draft Preparation, H.-W.W., M.K., D.T. and W.-C.K.; Writing-Review \& Editing, H.-W.W., M.K., D.T. and W.-C.K.; Visualization, W.-C.K.; Supervision, H.-W.W.; Project Administration, W.-C.K.

Funding: This research received no external funding.

Acknowledgments: The authors appreciate Chin-Ban Chen, a reservoir manager of Taiwan Sugar Corporation, Ling-Yu Huang, a manager of Taipower Company, and Jui-Fu Cheng, a staff working for the Water Resource Agency under Ministry of Economic Affairs in Taipei, for furnishing some of the very important information used in this paper. Kondolf acknowledges gratefully acknowledges the Collegium de Lyon-Institut des Etudes Avancées de l'Université de Lyon, the EURIAS Fellowship Programme and the European Commission (Marie-Sklodowska-Curie Actions-COFUND Programme-FP7) for partial support of manuscript preparation.

Conflicts of Interest: The authors declare no conflict of interest.

\section{References}

1. White, R. Evacuation of Sediments from Reservoirs; Thomas Telford Publishing: London, UK, 2001.

2. Palmieri, A.; Shah, F.; Dinar, A. Economics of reservoir sedimentation and sustainable management of dams. J. Environ. Manag. 2001, 61, 149-163. [CrossRef] [PubMed]

3. Minear, J.T.; Kondolf, G.M. Estimating reservoir sedimentation rates at large spatial and temporal scales: A case study of California. Water Resour. Res. 2009, 45. [CrossRef]

4. Kondolf, G.M. PROFILE: Hungry water: Effects of dams and gravel mining on river channels. Envirol. Manag. 1997, 21, 533-551. [CrossRef]

5. Doyle, M.W.; Stanley, E.H.; Harbor, J.M.; Grant, G.S. Dam removal in the United States: Emerging needs for science and policy. Eos Trans. Amer. Geophys. Union 2003, 84, 29-33. [CrossRef]

6. United States Army Corps of Engineers (USACE). Infrastructure Report Card; United States Army Corps of Engineers: Washington, DC, USA, 2017.

7. O'Connor, J.E.; Duda, J.J.; Grant, G.E. 1000 dams down and counting. Science 2015, 348, 496-497. [CrossRef] [PubMed]

8. Annandale, G.W.; Morris, G.L.; Karki, P. Technical Guidance Note: Extending the Life of Reservoirs-Sustainable Sediment Management for Run-of-River Hydropower and Dams; World Bank: Washington, DC, USA, 2016.

9. Morris, G.L.; Fan, J.X. Reservoir Sedimentation Handbook: Design and Management of Dams, Reservoirs, and Watersheds for Sustainable Use; McGraw-Hill Education: New York, NY, USA, 1998.

10. Palmieri, A.; Shah, F.; Annandale, G.W.; Dinar, A. Reservoir Conservation-Economic and Engineering Evaluation of Alternative Strategies for Managing Sedimentation in Storage Reservoirs: The RESCON Approach; The World Bank: Washington, DC, USA, 2003; Volume 1.

11. International Commission on Large Dams (ICOLD). Dealing with Reservoir Sedimentation; Bulletin Number 115, International Commission on Large Dams: Paris, France, 1999.

12. Kawashima, S.; Butler-Johndrow, T.; Annandale, G.; Shah, F. Reservoir Conservation: Economic and Engineering Evaluation of Alternative Strategies for Managing Sedimentation in Storage Reservoirs: RESCON Model and User Manua; World Bank: Washington, DC, USA, 2003; Volume 2.

13. Basson, G.R. Hydraulic measures to deal with reservoir sedimentation: Flood flushing, sluicing and density current venting. In Proceedings of the 3rd International Conference on River Flood Hydraulics, Stellenbosch, South Africa, 5-7 November 1997.

14. Harada, M.; Morimoto, H.; Kokubo, T. Operational results and effects of sediment bypass system. In Proceedings of the Transactions of the 20th Congress on Large Dams, Beijing, China, 19-22 September 2000.

15. Sumi, T.; Kantoush, S. Comprehensive sediment management strategies in Japan: Sediment bypass tunnels. In Proceedings of the 34th World Congress of the International Association for Hydro-Environment Research and Engineering, 33rd Hydrology and Water Resources Symposium and 10th Conference on Hydraulics in Water Engineering Valentine; Valentine, E.M., Apelt, C.J., Ball, J., Chanson, H., Cox, R., Ettema, R., Kuczera, G., Lambert, M., Melville, B.W., Sargison, J.E., Eds.; Engineers Australia: Barton, Australia, 2011. 
16. Auel, C.; Boes, R. Sediment Bypass Tunnel Design-Review and Outlook; Taylor \& Francis Group: London, UK, 2011.

17. Sumi, T. Evalutation of Efficiency of Reservoir Sediment Flushing in Kurobe River. In Proceedings of the 4th International Conference on Scour and Erosion (ICSE-4), Tokyo, Japan, 5-7 November 2008.

18. Kondolf, G.M.; Gao, Y.; Annandale, G.W.; Morris, G.L.; Jiang, E.; Zhang, J.; Cao, Y.; Carling, P.; Fu, K.; Guo, Q.; et al. Sustainable sediment management in reservoirs and regulated rivers: Experiences from five continents. Earth Future 2014, 2, 256-280. [CrossRef]

19. Sumi, T.; Kantoush, S.A. Integrated management of reservoir sediment routing by flushing, replenishing, and bypassing sediments in Japanese river basins. In Proceedings of the 8th International Symposium on Ecohydraulics, Seoul, Korea, 12-16 September 2010.

20. Boillat, J.-L.; Pougatsch, H. State of the art of sediment management in Switzerland. In Proceedings of the International Workshop and Symposium on Reservoir Sedimentation Management, Toyama, Japan, 21-22 March 2000.

21. Dadson, S.J.; Hovius, N.; Chen, H.; Dade, W.B. Links between erosion, runoff variability and seismicity in the Taiwan orogen. Nature 2003, 426, 648. [CrossRef] [PubMed]

22. Hwang, J.S. A Study of the Sustainable Water Resources System in Taiwan Considering the Problems of Reservoir Desilting; River Works Planning Department, Water Conservancy Bureau, Taiwan Provincial Government: Taichung, Taiwan, 1994.

23. Dadson, S.J.; Hovius, N.; Chen, H.; Dade, W.B.; Lin, J.C.; Hsu, M.L.; Lin, C.W.; Horng, M.J.; Chen, T.C.; Milliman, J. Earthquake-triggered increase in sediment delivery from an active mountain belt. Geology 2004, 32, 733-736. [CrossRef]

24. Chang, J.C. Natural hazards in Taiwan. GeoJournal 1996, 38, 251-257. [CrossRef]

25. Hsu, H.-H.; Chou, C.; Wu, Y.C.; Lu, M.M.; Chen, C.T.; Chen, Y.M. Climate Change in Taiwan: Scientific Report 2011; National Science Council Taiwan Climate Change Projection and Information Platform Project: Taichung City, Taiwan, 2011.

26. Water Resources Agency (WRA). Long-Term Monitoring of Sediment Transport in Shihmen Reservoir; Water Resources Agency: Taichung City, Taiwan, 2015.

27. Water Resources Agency (WRA). Long-Term Measurement of Sediment Transport and Density Current Simulation in Shihman Reservoir (1/2); Water Resources Agency: Taichung City, Taiwan, 2012.

28. Water Resources Agency (WRA). Long-Term Measurement of Sediment Transport and Density Current Simulation in Shihman Reservoir (2/2); Water Resources Agency: Taichung City, Taiwan, 2014.

29. Water Resources Agency (WRA). Feasibility Study of Amouping Desilting Tunnel Project for Shimen Reservoir-Summary Report; Water Resources Agency: Taichung City, Taiwan, 2015.

30. Water Resources Agency (WRA). Hydraulic Model Works on the Functions and Operations of Silting Prevention in A-Kung-Tien Reservoir in 1997; Water Resources Agency: Taichung City, Taiwan, 1998.

31. Water Resources Agency (WRA). Hydraulic Model Studies on the Functions and Operations of Silting Prevention in A-Kung-Tien Reservoir; Water Resources Agency: Taichung City, Taiwan, 1999.

32. Water Resources Agency (WRA). Hydraulic Model Studies on the Functions and Operations of Silting Prevention in A-Kung-Tien Reservoir; Water Resources Agency: Taichung City, Taiwan, 2000.

33. Water Resources Agency (WRA). Hydraulic Model Studies on the Functions and Operations of Silting Prevention in A-Kung-Tien Reservoir-Fiznal Report; Water Resources Agency: Taichung City, Taiwan, 2003.

34. Water Resources Agency (WRA). Tsengwen Reservoir Watershed Main Stream Desilting Sediment Survey and Removal Project; Water Resources Agency: Taichung City, Taiwan, 2001.

35. Adhikari, K.R.; Tan, Y.C.; Lai, J.S.; Chen, Z.S.; Lin, Y.J. Climate Change Impacts and Responses: A Case of Shihmen Reservoir in Taiwan. In Proceedings of the 2nd International Conference "Climate Change: Impacts and Responses", Brisbane, Australia, 08-10 July 2010; University of Queensland: Brisbane, Australia, 2010.

36. Wang, H.W.; Kondolf, G.M. Upstream Sediment-Control Dams: Five Decades of Experience in the Rapidly Eroding Dahan River Basin, Taiwan. J. Am. Water Resour. Assoc. 2014, 50, 735-747. [CrossRef]

37. Tullos, D.; Wang, H.W. Morphological responses and sediment processes following a typhoon-induced dam failure, Dahan River, Taiwan. Earth Surf. Process. Landf. 2014, 39, 245-258. [CrossRef]

38. Water Resources Agency (WRA). Study on Prospective Development of Public Water Supply Industry (2/2); Water Resources Agency: Taichung City, Taiwan, 2011. 
39. Lai, Y.G.; Thomas, R.E.; Ozeren, Y.; Simon, A.; Greimann, B.P.; Wu, K. Modeling of multilayer cohesive bank erosion with a coupled bank stability and mobile-bed model. Geomorphology 2015, 243, 116-129. [CrossRef]

40. Water Resources Agency (WRA). Preliminary Study for Sediment Sluicing and Flood Diversion Engineering of Shihman Reservoir-Preliminary Report; Water Resources Agency: Taichung City, Taiwan, 2010.

41. Water Resources Agency (WRA). Feasibility study of Dawanping Desilting Tunnel Project in Shihmen Reservoir Summary Report; Water Resources Agency: Taichung City, Taiwan, 2011.

42. Water Resources Agency (WRA). Evaluation of Morphological Effects in Downstream River due to Sediment Venting and Replenishment from the Shihmen; Water Resources Agency: Taichung City, Taiwan, 2014.

43. Water Resources Agency (WRA). Desilting Tunnel Project of Shimen Reservoir (First Stage)—The Basic Design Report of Amouping Tunnel; Water Resources Agency: Taichung City, Taiwan, 2016.

44. Water Resources Agency (WRA). Water Resources Agency Year Book in 2011; Water Resources Agency: Taichung City, Taiwan, 2012.

45. Water Resources Agency (WRA). Feasibility Study of Desilting Facilities Project in Ronghua Dam; Water Resources Agency: Taichung City, Taiwan, 2009.

46. Water Resources Agency (WRA). Directions on Wujie Reservoir Operation; Water Resources Agency: Taichung City, Taiwan, 2013.

47. Taipower Company (TC). Operation Rule of Wujie Dam and Water Intake; Taipower Company: Taipei City, Taiwan, 2011.

48. National Cheng Kung University (NCKU). Study on Reservoir Sedimentation in Mudstone Area of Southwest of Taiwan (I)-Reservoir Drilling and Soil Test Report; National Cheng Kung University: Tainan City, Taiwan, 1987.

49. Water Resources Agency (WRA). Effect Assessment of Empty Storage Operation for Sediment Prevention and Sand Observation Program of Agoden Reservoir in 2009; Water Resources Agency: Taichung City, Taiwan, 2009.

50. Water Resources Agency (WRA). Directions on Agondian Reservoir Operation; Water Resources Agency: Taichung City, Taiwan, 2007.

51. Wang, H.W.; Li, C.C.; Tsai, Y.J.; Tsai, B.S.; Kuo, W.C. Desilting Efficiency due to Empty Flushing of Agongdian Reservoir. In Proceedings of the 12th International Conference on Hydroscience \& Engineering, Tanan, Taiwan, 6-10 November 2016.

52. Batuca, D.G.; Jordaan, J.M., Jr. Silting and Desilting of Reservoirs; CRC Press: Rotterdam, The Netherlands, 2000.

53. Portland General Electric (PGE). Decommissioning Plan for the Bull Run Hydroelectric Project; FERC Project No. 477; Federal Energy Regulatory Commission Office of Hydropower Licensing: Washington, DC, USA, 2002.

54. United States Society on Dams (USSD). Guidelines for Dam Decommissioning Projects; United States Society on Dams: Denver, CO, USA, 2015; ISBN 978-1-884575-71-6.

55. Woelfle-Erskine, C.A.; Wilcox, A.C. Historical perspectives on channel pattern in the Clark Fork River, Montana and implications for post-dam removal restoration. In Proceedings of the American Geophysical Union Fall Meeting, San Francisco, CA, USA, 14-18 December 2009.

56. Kantoush, S.; Sumi, T.; Murasaki, M. Evaluation of sediment bypass efficiency by flow field and sediment concentration monitoring techniques. J.Jpn. Soc Civil Eng. 2011,67, I_169-I_174. [CrossRef]

57. Chung, C.-C.; Lin, C.-P. High concentration suspended sediment measurements using time domain reflectometry. J. Hydrol. 2011, 401, 134-144. [CrossRef]

58. Crosa, G.; Castelli, E.; Gentili, G.; Espa, P. Effects of suspended sediments from reservoir flushing on fish and macroinvertebrates in an alpine stream. Aquat. Sci. 2010, 72, 85. [CrossRef]

59. Espa, P.; Brignoli, M.L.; Crosa, G.; Gentili, G.; Quadroni, S. Controlled sediment flushing at the Cancano Reservoir (Italian Alps): Management of the operation and downstream environmental impact. J. Environ. Manag. 2016, 182, 1-12. [CrossRef] [PubMed]

60. Kjelland, M.E.; Woodley, C.M.; Swannack, T.M.; Smith, D.L. A Review of the Potential Effects of Suspended Sediment on Fishes: Potential Dredging-Related Physiological, Behavioral, and Transgenerational Implications. Environment Systems and Decisions; Springer: New York, NY, USA, 2015; Volume 35, pp. 334-350.

61. Wenger, A.S.; Harvey, E.; Wilson, S.; Rawson, C.; Newman, S.J.; Clarke, D.; Saunders, B.J.; Browne, N.; Travers, M.J.; McIlwain, J.L. A critical analysis of the direct effects of dredging on fish. Fish. Fish. 2017. [CrossRef] 
62. Servizi, J.A.; Martens, D.W. Sublethal responses of coho salmon (Oncorhynchus kisutch) to suspended sediments. Can. J. Fish. Aquat. Sci. 1992, 49, 1389-1395. [CrossRef]

63. Water Resources Agency (WRA). Maintaining a Sustainable Tsengwen Reservoir Planning Report; Water Resources Agency: Taichung City, Taiwan, 2014. 